\title{
THE INCENTIVE EFFECTS OF EQUALIZATION GRANTS ON FISCAL POLICY ${ }^{\dagger}$
}

\section{Ergete Ferede}

\section{SUMMARY}

The equalization system has long been considered a vital underpinning of the Canadian federation: a means to create some purported fairness or justice among the provinces, by redistributing the wealth of provinces with larger fiscal capacities to allow those with weaker fiscal capacities to provide roughly equivalent services to their citizens. However, the mechanics of the equalization formula have long been suspected of being flawed. Since grant-receiving provinces can adjust the way their fiscal capacities are calculated and reflected in the equalization formula - by adjusting tax rates and spending, for instance - governments are confronted with incentives to design their fiscal regimes in ways that maximize the size of the grants they receive, even if the fiscal policies are designed for less-than-optimal economic efficiency. The incentive for grant-receiving governments to "game" the formula, even unconsciously, is apparent; what has remained largely unresolved is to what extent is it actually occurring.

This analysis shows that indeed it is occurring, and to a measurable degree. It finds that equalization grants provide recipient provinces with incentive to raise their business and personal tax rates. This is because when a government raises its own tax rate, it raises the national standard average tax rate, which is used in the equalization allocation formula. That, in turn, raises the individual "have-not" province's equalization-grant entitlement. Exacerbating the problem is that the tax-raising provincial governments tend to underestimate the deadweight cost that the tax hikes will have, potentially worsening the fiscal situation of a province that already faces difficult economic challenges.

This analysis also finds that the equalization-grant allocation system encourages spending among recipient provinces, particularly on health-care services, resource conservation, industrial assistance, environment and housing. Results show that for every $\$ 1.00$ increase in equalization grants, recipient provinces further increase spending by an additional $\$ 0.64$ in total expenditure.

Neither effect necessarily furthers the equalization program's idealistic intent. The promotion of higher tax rates especially would seem to work at odds with the program's conceptualization of a federal redistribution model. By potentially further repelling business and taxpayers from "have-not" provinces, the result could be making those provinces increasingly needy while continually reducing their citizens' wealth.

The equalization formula is not unfixable. The arrangement can be made to work even better, in a way that maintains the principle of redistributing wealth from more privileged provinces to less privileged ones, while avoiding the perverse incentives that motivate "have-not" provinces to raise taxes. If equalization grants were substituted with block grants that are unrelated to taxing capacity, taxes in grant-receiving provinces may actually decline. A $\$ 100$ per capita increase in block grants is potentially associated with an up to 2.6 percentage points drop in business tax and an up to 0.26 percentage point drop in personal income tax. The result would be an equalization arrangement that could help increase, rather than decrease, competitiveness in the very "have-not" provinces that most urgently need to attract investment. Switching to block grants would not only keep the integrity of the principles behind equalization in tact, it would actually make equalization work better for all provinces. 


\section{INTRODUCTION}

Equalization-grant systems have been the cornerstones of intergovernmental fiscal relationships in federations such as Australia, Canada, Germany, Switzerland and others. In the literature, fiscal equity and efficiency have been put forward as major justifications for the presence of such grants. ${ }^{l}$

In Canada, the equalization system was designed to address provincial fiscal disparities by compensating recipient provinces when their per capita tax base is below the standard per capita tax base. Theoretical analyses by both Smart and Dahlby ${ }^{2}$ show that in equalization programs based on a representative tax system, such as the one used in Canada, equalization grants influence recipient provinces' tax policy incentives. The reason is that when a recipient province raises its tax rate, it gets higher equalization entitlements by increasing the national standard tax rate. Further, the province can receive higher equalization grants due to a reduction in the province's tax base associated with a rise in its tax rate. These tax-rate and tax-base effects of equalization grants cause a downward bias of the marginal cost of public funds (MCF) and, as a result, the grant system gives recipient provinces an incentive to raise their tax rates.

Previous empirical studies, such as those by Courchene and Beavis, Boessenkool, Esteller-Moré and Solé-Ollé, Snoddon and Smart, ${ }^{3}$ also confirm that the equalization system influences tax policy incentives in Canada. For other federations, Buettner ${ }^{4}$ finds that equalization grants provide German municipalities an incentive to raise their tax rates. Dahlby and Warren, on the other hand, find only weak evidence for Australian states. ${ }^{5}$

While the incentive effects of equalization grants on tax policy are well known and have been widely examined in previous studies, there is a paucity of studies on its effects on government spending. Since the Canadian equalization-grant formula compensates recipient provinces when their per capita tax base is below the standard per capita tax base, Dahlby shows that this gives the recipient provinces the incentive to under-provide tax-base-enhancing public services. ${ }^{6}$

1 See, for instance: R. Boadway and F. Flatters, "Efficiency and equalization payments in a federal system of government: a synthesis and extension of recent results," Canadian Journal of Economics 15 (1982): 613-33; P. Boothe and D. Hermanutz, "Simply Sharing: An Intergovernmental Equalization Scheme for Canada," C.D. Howe Institute Commentary (Toronto: C.D. Howe Institute, 1999); M. Köthenbürger, "Tax competition and fiscal equalization," International Tax and Public Finance 9 (2002): 391-408; and R. Boadway, "The theory and practice of equalization," CESifo Economic Studies 50 (2004), 211-254.

2 M. Smart, "Taxation and deadweight loss in a system of intergovernmental transfers," Canadian Journal of Economics 31 (1998): 189- 206; B. Dahlby, "The Incentive Effects of Fiscal Equalization Grants", in Equalization: Welfare Trap or Helping Hand?, ed. Paul Boothe (Halifax: Atlantic Institute for Market Studies, 2002).

3 T. Courchene, and D. Beavis, "Federal-provincial tax equalization: an evaluation," Canadian Journal of Economics 6 (1973): 483-502; K. Boessenkool, "Taxing Incentives: How Equalization Distorts Tax Policy in Recipient Provinces," AIMS Equalization Papers 3, ed. Brian Lee Crowley (Halifax: Atlantic Institute of Market Studies, 2002); A. EstellerMoré and A. Solé-Ollé, "An empirical analysis of vertical tax externalities: the case of personal income taxation in Canada," International Tax and Public Finance 9 (2002): 235-57; T. Snoddon, "On Equalization and Incentives: An Empirical Assessment," Discussion Paper (Waterloo, Ont.: Wilfrid Laurier University, 2003); and M. Smart, "Raising taxes through equalization," Canadian Journal of Economics 40 (2007): 1188-1212.

4 T. Buettner, "The Incentive Effect of Fiscal Equalization Transfers on Tax Policy," Journal of Public Economics 90 (2006): 477-497.

5 B. Dahlby and N. Warren, "The fiscal incentive effects of the Australian equalization system," Economic Record 79 (2003): 434-445.

6 Dahlby, "The Incentive Effects." 
Cyrenne and Pandey offer the first empirical analysis on the effects of equalization grants on the composition of Canadian provincial expenditure. ${ }^{7}$ They find that the share of unproductive government expenditure is higher and the share of productive government expenditure is lower in the recipient provinces compared to non-receiving provinces. ${ }^{8}$ Using data from German municipalities, Hauptmeier also finds that equalization transfers have a significant negative effect on local government's share of productive expenditure. 9

The main objective of this paper is to provide empirical evidence on the incentive effects of equalization grants on tax rates and government expenditure using panel data from Canadian provinces over the period 1981-2008. Regarding the incentive effects of equalization grants on tax policy, we focus on business and personal income tax rates, as these taxes account for a significant part of provincial tax revenue and have been the topic of discussion in previous studies. In addition, these revenue categories have been included in the equalization-grant allocation formula throughout the period under consideration. In our empirical analysis, following Buettner, ${ }^{10}$ we differentiate the income and incentive effects of equalization grants. The incentive effects associated with the equalization system arise due to the equalization-rate and -base effects that cause a downward bias of the MCF. In this paper we investigate this issue by estimating both the equalization-rate and equalization-base effects, and controlling for possible income effects associated with equalization grants. As the equalization-grant formula shows a discontinuity in the relationship between equalization-grant entitlement and fiscal capacity, we rely on this discontinuity to identify the effects of grants on tax rates. To the best of our knowledge, this paper is the first to address this issue for Canada.

Our empirical results suggest that equalization grants provide provincial governments an incentive to raise their business and personal income tax rates. We also find that the incentive effect works mainly through the equalization-base effects. These incentive effects of equalization grants are clearly a form of distortion to provincial tax policy as the recipient governments underestimate the true deadweight cost associated with the higher tax rates. Our results suggest that if equalization grants were substituted with block grants that are not related to taxing capacity, business and personal income tax rates would be lower in the grantreceiving provinces.

We also investigate the effects of equalization grants on both the level and composition of provincial expenditure using the discontinuity in the equalization-grant formula as an identification strategy. Our empirical results suggest that equalization grants stimulate provincial spending and affect the various provincial expenditure categories. Results from our preferred regression indicate that a $\$ 1.00$ increase in per capita equalization grant is associated with $\$ 0.64$ increase in per capita total provincial expenditure. This is broadly consistent with

7 P. Cyrenne and M. Pandey, "Fiscal equalization, government expenditure and endogenous growth," Working Paper (Winnipeg: University of Winnipeg, 2013).

8 Cyrenne and Pandey (ibid.) use three broad expenditure categories. They classify provincial expenditures on health, education, transportation and communication, general government services, transfers to other governments, and housing as "productive." They also categorize provincial expenditures on social services and recreation and culture as "unproductive." Their third category, "others," on the other hand, includes all the other remaining expenditures.

9 S. Hauptmeier, "The impact of fiscal equalization on local expenditure policies: theory and evidence from Germany" ZEW Discussion Papers 07-081 (2007).

10 Buettner, "The Incentive Effect." 
the flypaper literature and the estimated results are well within the ranges of results obtained in other similar studies. Further, our results indicate that equalization grants have a significant positive effect on provincial spending on health-care services, resource conservation, industrial assistance, environment, and housing. However, we do not find a significant effect on the other expenditure categories. Overall, our results suggest that the Canadian equalization system influences recipient provinces' tax and spending decisions.

The remainder of the paper is organized as follows. In Section 2, we provide a brief review of theoretical and empirical studies of the effects of equalization grants on fiscal policy. An empirical analysis of the effects of equalization grants on tax policy incentives for Canadian provincial governments is presented and discussed in Section 3. In Section 4, we examine how equalization grants influence the level and composition of provincial governments' expenditure. Section 5 concludes.

\section{LITERATURE REVIEW}

Fiscal equity and efficiency have been put forward as major justifications for the presence of equalization systems in federations. ${ }^{l l}$ Regardless of the rationales for their existence, however, there is a great potential for equalization systems to influence fiscal policy incentives. In this section, we provide a brief review of the literature on the incentive effects of equalization programs on tax policy and government spending.

The incentive effects of equalization grants on tax policy are in fact well known and have been widely examined in previous studies. For instance, an earlier analysis of the Canadian equalization system by Courchene and Beavis suggests that recipient provinces could manipulate the equalization allocation formula to increase their equalization entitlements. ${ }^{12}$ The reason is that, in the Canadian equalization system, the main elements of the formula can be affected by the tax policy choice of the recipient province.

Smart presents the first theoretical analysis of the effects of equalization grants on tax policy incentives using the marginal cost of public funds (MCF) framework. ${ }^{13}$ He shows that representative-tax-system-based (RTS-based) equalization grants, such as the one used in Canada, partially compensate for the deadweight loss associated with higher taxes and, as a result, it gives recipient provinces the incentive to raise tax rates. Thus, subnational governments may adopt suboptimal tax policies in order to gain more transfer payments from the equalization system. This is because if tax-base elasticities are negative, as many empirical studies show, provinces may have the incentive to raise tax rates, which will result in a reduction in their fiscal capacities and more equalization transfers.

\footnotetext{
11 See, for instance: Boadway and Flatters, "Efficiency and equalization"; Boothe and Hermanutz, "Simply Sharing"; Kőthenbürger, "Tax competition”; and Boadway, "The theory and practice."

12 Courchene and Beavis, "Federal-provincial."

13 Smart, "Taxation and deadweight."
} 
Dahlby also provides a comprehensive theoretical analysis of how equalization grants influence both the tax and expenditure decisions of recipient governments. ${ }^{14}$ Regarding tax policy incentive effects of equalization systems, his analysis indicates that equalization grants reduce the perceived MCF of recipient governments and provides them an incentive to raise their tax rates. He shows that there are multiple reasons for this. When a recipient government raises its tax rate, the national standard tax rate increases and this provides the MCF of the recipient government a downward bias. Further, an increase in the tax rate reduces the tax base of the province and this also biases the MCF downward. The downward bias of the MCF caused by the tax-rate and tax-base effects associated with equalization grants ultimately leads recipient provinces to underestimate the true social cost of taxes. The implication of this is that the equalization system provides recipient provinces an incentive to raise their tax rates.

While the above studies focus on the theoretical underpinning of the incentive effects of equalization systems on tax policy, others investigate the issue empirically. ${ }^{15}$

One of the earliest attempts to gauge the tax incentive effects of equalization grants in Canada is offered by Boessenkool. ${ }^{16} \mathrm{He}$ investigates how the Canadian equalization-grant system affects tax incentives by comparing the average effective tax rates of recipient provinces to those of comparable non-recipient provinces. His analysis suggests that equalization-grant receiving provinces generally levy higher tax rates than non-recipients.

Esteller-Moré and Solé-Ollé empirically estimate the effects of equalization grants on Canadian provincial personal income tax rates (PIT).$^{17}$ Their dependent variable is average effective tax rate, and they capture the effect of equalization grants by including the national standard average effective tax rate for PIT (interacted with the equalization-receiving dummy variable) as an explanatory variable. They also include the weighted average tax rate of contiguous neighbouring provinces as a separate co-variate in their regression model. Their results suggest that equalization grants have a significant positive effect on provincial personal income tax rates.

Over the years, the Canadian equalization system has passed through various policy changes. One such policy change occurred in 1982, when the federal government adopted the fiveprovince standard instead of the 10-province standard that was in effect prior to that. Snoddon exploits this policy change and provides an in-depth examination of the effects of equalization grants on the growth rate of own-source revenue for Canadian provinces. ${ }^{18}$ She uses the change in the number of standard provinces as the main identifying strategy to investigate the shortrun revenue effects of equalization grants. Her main objective is to examine whether the equalization reform has an effect on own-source revenue growth in the years following the equalization-grant reform. She estimates the effect of the equalization reform on own-source revenue using dummy variables for the two years immediately following the reform. The

\footnotetext{
14 Dahlby, "The Incentive Effects."

15 These studies include, for the Canadian federation: Boessenkool, "Taxing Incentives"; Esteller-Moré and Solé-Ollé, "An empirical analysis"; Snoddon "On Equalization”; and Smart, "Raising taxes.” For Germany: C. Baretti, B. Huber, K. Lichtblau, "A tax on tax revenue: the incentive effects of equalizing transfers: evidence from Germany," International Tax and Public Finance 9 (2002): 631-649; and Buettner, "The Incentive Effect." And for Australia: Dahlby and Warren, "The fiscal incentive."

16 Boessenkool, "Taxing Incentives."

17 Esteller-Moré and Solé-Ollé, "An empirical analysis."

18 Snoddon, "On Equalization."
} 
empirical analysis also employs various dummy variables to capture differential effects associated with equalization-grant receiving provinces and those that are included or excluded from the standard. The analysis is conducted for all provinces and for individual recipient provinces separately. Her empirical results suggest that the reform has a positive effect on the own-source revenue growth of those equalization-grant receiving provinces excluded from the new standard. This is consistent with the general belief that the equalization system influences tax policy incentives. The result, however, is negative for Quebec.

Smart investigates the effects of equalization grants on tax policy, and how the presence of such grants influence tax competition among Canadian provinces. ${ }^{19}$ His theoretical framework provides two testable propositions: equalization grants increase the complementarity of competitors' tax rates; and, that an increase in the fraction of revenues equalized through the grant allocation formula raises the tax rates of receiving provinces. Using annual Canadian provincial data over the period 1972-2002, he tests the propositions of the theoretical model empirically. In the empirical analysis, he measures the effect of equalization grants on tax policy incentive by looking at the effect of the average effective tax rate of other provinces on the effective tax rate of the province, and distinguishing the differential effects of grants between receiving and non-receiving provinces. An increase in the average effective tax rate of other provinces raises the national standard tax rate that is used in the equalization-grant allocation formula. This in turn increases the equalization grant for receiving provinces. His analysis makes use of this relationship to identify the effects of equalization grants on tax policy incentives. His results indicate that equalization-grant recipient provinces respond more positively to increases in other provinces' average effective tax rates, suggesting that indeed the equalization system influences tax policy incentives.

Germany is one of the countries that have had a longstanding equalization-grant system. Unlike Canadian provinces, however, German states do not levy their own taxes. Instead, the federal government imposes the taxes and the states collect the tax revenue in their jurisdictions. In this case, the amount of tax revenue collected in each state depends on the enforcement efforts of the states. Baretti, Huber and Lichtblau examine the effects of equalizing transfers on tax policy for German states. ${ }^{20}$ They look at how equalization transfers affect states' tax enforcement, which in turn affects the amount of tax revenue the recipient governments collect. Their ordinary least squares estimation results show that equalizing grants have a negative effect on a state's tax revenue-to-GDP ratio. They interpret this as a negative effect of equalization grants on tax-enforcement efforts of the states. However, their results become insignificant when they use fixed-effects and other methods. So they find only weak evidence that equalization grants affect tax revenue negatively.

Buettner investigates the effects of equalization transfers on business tax rates for municipalities in a German state. ${ }^{21}$ The municipal fiscal equalization system in Germany takes into account disparities in fiscal need and fiscal capacity. Buettner introduces a novel idea to distinguish the income effect and the tax-incentive effect associated with the equalization system. He shows that the equalization formula can be written as a difference of two basic components: "virtual grants" and "marginal contribution rate" (times the tax base). The "virtual grant" is the part of an equalization grant that does not depend on the tax base of the recipient

\footnotetext{
19 Smart, "Raising taxes."

${ }^{20}$ Baretti, Huber and Lichtblau, "A tax on tax."

${ }^{21}$ Buettner, "The Incentive Effect."
} 
jurisdiction and it shows the amount of grants that municipalities would receive if their tax bases were zero. The "marginal contribution rate," on the other hand, captures the fact that when a local government's tax base increases, in the equalization formula its fiscal capacity rises and as a result it receives smaller grants. In the empirical analysis, he exploits the discontinuity in the equalization-grant formula and uses policy changes to identify the effects of equalization grants on business tax rates. The results indicate that while higher virtual grants are associated with lower business tax rates, a higher marginal contribution rate provides the local governments an incentive to raise their tax rates. Thus, his analysis provides empirical support for the hypothesis that equalization grants influence tax policy incentives.

As in Canada, the Australian equalization-grant allocation formula depends on the fiscal capacity of the state relative to that of the standard fiscal capacity. Dahlby and Warren employ the marginal cost of public funds (MCF) framework to analyze the incentive effects of the Australian equalization system. ${ }^{22}$ They show that equalization grants can affect a state's tax policies through the "equalization-rate effect" and the "equalization-base effect." When a state raises its tax rate, the average standard tax rate used in the grant allocation formula increases. This equalization-rate effect results in higher equalization grants for the state, provided that the state's relative fiscal capacity is low. The equalization-base effect, on the other hand, refers to the increase in equalization grants that results from a reduction in a state's tax base associated with a rise in its tax rate. They derive a formula for the MCF, which depends on the standard tax rate standard tax base, and the tax base of the state. They show that equalization-rate and base effects lead to a downward bias of the MCF and provide recipient provinces the incentive to raise their tax rates. They then use data from Australian states to examine the tax-incentive effects of equalization grants. They find somewhat weak empirical evidence that the equalization system affects Australian states' tax-rate choices.

While the tax-incentive problem associated with equalization grants is widely discussed in the literature, there is a paucity of studies about the potential incentive effects of such grants on government expenditures. In the literature, the effects of unconditional transfers such as equalization grants on the recipient government's total expenditure are often discussed in conjunction with the flypaper effect - a common empirical finding that lump-sum grants increase the recipient subnational government's expenditure more than an equivalent increase in income.

The majority of the flypaper-effect literature concludes that unconditional grants raise total expenditure, providing indirect evidence that equalization grants may also affect total expenditure. ${ }^{23}$ For the Canadian federation, Winer finds that grants raise provincial expenditure by reducing the perceived cost of provincial public services. ${ }^{24}$ Similar positive effects of unconditional grants on total expenditure are also obtained for other countries by Dahlberg et al. ${ }^{25}$ for Sweden, and Lundqvist ${ }^{26}$ for Finland.

22 Dahlby and Warren, "The fiscal incentive."

${ }^{23}$ For a recent survey of the literature, see: S. Gamkhar and A. Shah, "The impact of intergovernmental transfers: a synthesis of the conceptual and empirical literature," in Intergovernmental Fiscal Transfers: Principles and Practice (Washington, D.C.: The World Bank, 2007).

24 S. Winer, "Some evidence on the effect of the separation of spending and taxing decisions," Journal of Political Economy 91 (1983): 126-140.

25 M. Dahlberg et al., "Using a discontinuous grant rule to identify the effect of grants on local taxes and spending," Journal of Public Economics 92 (2008): 2320-2335.

${ }^{26}$ H. Lundqvist, "Granting public or private consumption? Effects of grants on local public spending and income taxes," International Tax and Public Finance (2013), DOI 10.1007/s10797-013-9279-7. 
Of course, in addition to their potential effects on total expenditure, equalization grants may influence the composition of government expenditure. In fact, previous studies such as Dahlby, ${ }^{27}$ Hauptmeier ${ }^{28}$ and Cyrenne and Pandey ${ }^{29}$ suggest that equalization grants influence the composition of government spending. Dahlby investigates this issue using the concept of MCF in the optimal public spending framework.$^{30} \mathrm{He}$ uses a simple productive-enhancing public input in the production function. If the public input is labour-augmenting, Dahlby shows that the recipient government will under-provide the public input. Thus, his analysis suggests that equalization grants give recipient governments the incentive to spend relatively more on consumptive expenditures and less on those public services and expenditure that enhance the tax base of the government. The reason is that when governments spend more on tax-baseenhancing expenditures such as education and infrastructure, the tax base of the province increases and this reduces the amount of equalization grant that the province might receive. This gives the province a disincentive to spend on such services. Spending on pure consumptive services, on the other hand, will not have an adverse effect on the amount of the equalization grant the province receives as tax bases are less likely to be affected by such spending.

Recently, using an endogenous growth model with optimal choice of government expenditure, Cyrenne and Pandey analyze the effects of equalization grants on the composition of government expenditure. ${ }^{3 l}$ They assume that the government provides productive public spending that enters the production function and increases economic growth, ultimately raising the fiscal capacity of the government. The government is also assumed to provide unproductive, or consumptive public services, that enter the utility function. In this model setup, they show that along the balanced-growth path, equalization-grant receiving provinces choose a higher unproductive government-spending ratio than non-receiving provinces. They then test the implications of their theoretical model using Canadian provincial panel data for the period 1989-2009. In their empirical analysis, they first classify provincial expenditures as being "productive" or "unproductive" and use the ratios of these expenditure groups to total expenditure as their dependent variables. They capture the effect of equalization grants on productive or unproductive expenditure ratios by including a dummy variable for equalizationgrant recipient provinces among the explanatory variables. Their empirical results show that, while the coefficient of the equalization dummy variable is negative and significant in the productive-expenditure ratio regression, the dummy variable is positive and significant in the unproductive-expenditure ratio equation. They interpret these results as evidence that the share of unproductive government expenditure is higher and the share of productive government expenditure is lower in the recipient provinces compared to non-receiving provinces.

\footnotetext{
27 Dahlby, "The Incentive Effects."

${ }^{28}$ Hauptmeier, "The impact of."

${ }^{29}$ Cyrenne and Pandey, "Fiscal equalization."

30 Dahlby, "The Incentive Effects."

31 Cyrenne and Pandey, "Fiscal equalization."
} 
For German municipalities, Hauptmeier investigates the effects of equalization transfers on local governments' expenditure policies. ${ }^{32}$ The author focuses on analyzing the effect of equalization grants on the share of local productive spending (which includes spending on schools and municipal roads). As in Buettner, ${ }^{33}$ he exploits the discontinuity in the German municipal equalization formula and uses a regression discontinuity approach to identify the effects of grants. He finds that equalization transfers have a significant negative effect on local government's share of productive expenditure.

Overall, the various studies surveyed above suggest that equalization-grant systems affect fiscal policy incentives in recipient subnational governments. In the next section, we explore these issues empirically using Canadian provincial data to shed some light on how the equalization system influences tax policy and government spending incentives.

\section{EQUALIZATION GRANTS AND TAX POLICY}

\section{Theoretical framework}

In this section, we discuss the theoretical framework that shows how equalization grants influence tax policy incentives of recipient provinces. Let $p$ represent the province and $j$ denote the tax category. Then, the per capita total revenue for provincial government $p$ for tax category $j$ is given as:

$$
R_{p j}=\tau_{p j} B_{p j}+g_{p j}
$$

where $R_{p j}$ is per capita revenue, $\tau_{p j}$ is the province's tax rate for tax category $j, B_{p j}$ is per capita tax base for the tax category $j$, and $g_{p j}$ is per capita equalization entitlement of province $p$ for tax category $j$. Suppose $\bar{\tau}_{j}$ denotes the national standard average tax rate for revenue source $j$ and $\bar{B}_{j}$ denotes the standard per capita tax base for revenue category $j$, then the per capita equalization-grant entitlement related to the $j$ tax source for province $p$ is simply:

$$
g_{p j}=\bar{\tau}_{j}\left(\bar{B}_{j}-B_{p j}\right)
$$

where:

$$
\bar{\tau}_{j}=\frac{\sum_{p=1}^{10} \tau_{p j} B_{p j}}{\sum_{p=1}^{10} B_{p j}}
$$

is the national standard tax rate and $g_{p j}$ is the equalization-grant entitlement related to tax category $j$.

\footnotetext{
32 Hauptmeier, "The impact of."

33 Buettner, "The Incentive Effect."
} 
Note that in Equation (2a), the receiving provinces' tax-rate choices can influence the national standard tax rate, and hence, the amount of grant it receives. If the receiving province is also part of the standard provinces, its tax base also affects the amount of grants that it receives through the change in the standard tax base. So, the grant allocation formula can be influenced by the tax policy choice of the receiving provinces. As our primary focus is to analyze the effect of equalization grants on tax policy incentives, we decompose the equalization allocation formula into two parts: the parts of the formula that can and cannot be influenced by the tax policy of the recipient province. In order to do that, following Buettner, ${ }^{34}$ we rewrite the grant allocation formula shown in Equation (2a) as:

$$
g_{p j}=y_{p j}-v_{p j} B_{p j}
$$

where $y_{p j}$ denotes what Buettner termed as "virtual grants" and it is the amount of equalization grant that province $p$ would receive if its tax base $j$ were actually zero. More specifically, the virtual equalization grant for any tax category is calculated as $y_{p j}=\bar{\tau}_{-p j} \bar{B}_{-p j}$, where $\bar{\tau}_{-p j}$ is the average effective tax rate of other provinces in the federation and $\bar{B}_{-p j}$ is the average per capita tax base of standard provinces (excluding the province's tax base if the province is part of the standard). If the province is not part of the "standard" provinces, then $\bar{B}_{-p j}=\bar{B}_{p j}$.

Unlike the case of Germany that Buettner examined, ${ }^{35}$ in the Canadian equalization-grant system, $v_{p j}$ is not a fixed parameter. It depends on the national standard tax rate and the relative fiscal capacity of the province - both of which can be influenced by the tax policy choice of the recipient province. We obtain $v_{p j}$ using the expression

$$
v_{p j}=\bar{\tau}_{-p j}\left(1-\Pi_{s}\right)-\left(\bar{\tau}_{p j}-\bar{\tau}_{-p j}\right)\left(\frac{\bar{B}_{j}}{B_{p j}}-1\right),
$$

where $\Pi_{s}$ is the population share of a province $p$ (that is included in the standard) from the total population of all the standard provinces, and the other variables are as defined before. If a province is not part of the standard provinces, $\Pi_{s}$ is equal to zero. As Smart explains ${ }^{36}$ the recipient provinces' tax rates and bases affect the national standard tax rate and, as a result, provincial tax policy choices can influence equalization-grant entitlements. For grant-receiving provinces that are included in the standard, they can also influence equalization entitlements through changes in the standard tax base. Thus, as we will see later, $v$ captures the effects of a receiving province's tax policy choice on the amount of equalization-grant entitlements.

\footnotetext{
34 ibid.

35 ibid.

36 Smart, "Taxation and deadweight."
} 
In order to discuss the incentive effects of equalization grants on tax policy, we use the marginal cost of public funds (MCF) framework. The MCF shows the cost to society when the government raises $\$ 1.00$ of tax revenue. In the absence of grants, the MCF for tax category $j$ can be calculated as:

$$
M C F_{p j}=\frac{B_{p j}}{B_{p j}+\tau_{p j}\left(\frac{d B_{p j}}{d \tau_{p j}}\right)}
$$

where $B$ is the tax base and $\tau$ is the tax rate. In the presence of federal equalization grants to the provinces, using Equation (1), the MCF for the recipient provincial government is given as:

$$
M C F_{p j}=\frac{B_{p j}}{B_{p j}+\left[\tau_{p j}-v_{p j}\right] \frac{d B_{p j}}{d \tau_{p j}}-B_{p j}\left[\frac{d v_{p j}}{d \tau_{p j}}+\frac{d v_{p j}}{d B_{p j}} \cdot \frac{d B_{p j}}{d \tau_{p j}}\right]}
$$

Equation (4) shows that the presence of equalization grants affect the MCF of the province, and hence, influence the tax policy incentives of the recipient provinces. Note that if $v_{p j}$ was based on a fixed parameter, as is the case in other federations such as Germany, Equation (4) would be reduced to the MCF expression used in Buettner. ${ }^{37}$ However, in the Canadian federation, as Smart $^{38}$ and Dahlby ${ }^{39}$ discuss, the third expression in the denominator of Equation (4) is non-zero and the effect of $v_{p j}$ on the MCF is not straightforward. To shed some light on the incentive effects of equalization grants on provincial tax policy, we further simplify the above equation. Using Equation (4) and the definitions of the various variables, following Dahlby and Dahlby and Warren, ${ }^{40}$ we can rewrite the MCF equation as:

$$
M C F_{p j}=\frac{1}{1+\frac{\tau_{p j} d B_{p j}}{B_{p j} d \tau_{p j}}+\Theta_{p j}+\psi_{p j}}
$$

where:

$$
\Theta_{p j}=\omega_{p}\left(\frac{\bar{B}_{j}}{B_{p j}}-1\right) \text { and } \psi_{p j}=-\bar{\tau}_{j}\left(1-\Pi_{s}\right) \varepsilon_{p j}
$$

$\omega_{p}$ is the tax-base share of the province in the federation, $\varepsilon_{p j}$ is the semi-elasticity of the tax base with respect to its own tax rate, and the other variables are as defined previously. Note that, as tax bases normally respond negatively to their own tax-rate changes (except of course when the province is on the downward sloping side of the Laffer curve), $\varepsilon_{p j}<0$ and, as a result, $\psi_{p j}>0$. When a province raises its tax rate, the tax base shrinks and this results in a fall in its relative fiscal capacity. A fall in the province's relative fiscal capacity in turn results in an

\footnotetext{
37 Buettner, "The Incentive Effect."

38 Smart, "Taxation and deadweight."

39 Dahlby, "The Incentive Effects."

40 ibid.; Dahlby and Warren, "The fiscal incentive."
} 
increase in its equalization-grant entitlement associated with the tax category. Thus, $\psi_{p j}$ captures the increase in the province's equalization grant caused by the fall in its relative fiscal capacity as its tax base falls (due to the increase in the tax rate). This is the equalization-base effect that Dahlby, and Dahlby and Warren referred to. ${ }^{41}$ See also Smart for an earlier discussion of this issue. ${ }^{42}$ Equation (5) shows that the equalization-base effect, $\psi_{p j}$, gives the recipient province's MCF a downward bias. Thus, this gives the recipient government an incentive to raise its tax rate.

For any given revenue category, when a provincial government raises its tax rate, it raises the national standard average tax rate used in the equalization allocation formula. This increases the recipient government's equalization-grant entitlement. Dahlby and Warren termed this as the equalization-rate effect ${ }^{43}$ This equalization-rate effect is denoted by $\Theta_{p j}$ in Equation (5). For provinces that are relatively small and have negligible effects on the national standard tax rate, $\Theta$ reduces to zero. For this reason, previous studies, such as Smart, ${ }^{44}$ ignore this effect from their analysis. Note also that the effect of $\Theta_{p j}$ on the MCF depends on whether the per capita tax base of the province is higher or lower than the standard per capita tax base for the specific revenue category. If the province's per capita tax base is less than the per capita tax base of the standard provinces (as is normally the case for equalization-grant recipients), $\Theta_{p j}$ will be positive, resulting in a downward bias of the recipient government's MCF. This provides the recipient government an incentive to raise its tax rate.

\section{Empirical specification and methodology}

Based on the theoretical framework discussed above, our empirical analysis of the effects of equalization grants on tax rates for revenue category $j$ can be specified as:

$$
\tau_{p j}=f\left(y_{p j}, \psi_{p j}, \Theta_{p j} ; Z_{p}\right)
$$

where $\tau_{p j}$ is the tax rate, $y_{p j}$ is the virtual equalization grant associated with the tax category, $\psi_{p j}$ is the equalization-base effect, $\Theta_{p j}$ is the equalization-rate effect, and $Z_{p}$ denotes a vector of other variables that can influence the tax-rate choices of a province. We are interested in assessing the incentive effects of equalization grants on personal and business income tax rates. These two revenue categories together account for a significant source of revenue for the provincial governments and have been the focus of previous studies as well. ${ }^{45}$

\footnotetext{
41 Dahlby, "The Incentive Effects"; Dahlby and Warren, "The fiscal incentive."

42 Smart, "Taxation and deadweight."

43 Dahlby and Warren, "The fiscal incentive."

44 Smart, "Taxation and deadweight."

45 For instance, for the last year of the period under consideration (fiscal year 2008/2009), these two tax categories account for about 42 per cent of the total tax revenue for the 10 provinces.
} 
The empirical specification can formally be expressed in the following form:

$$
\begin{aligned}
\tau_{p j, t}= & \alpha_{0}+\alpha_{1} y_{p j, t}+\alpha_{2} \Theta_{p j, t}+\alpha_{3} \psi_{p j, t}+\alpha_{4} D+ \\
& \alpha_{5} D \cdot \Theta_{p j, t}+\alpha_{6} D \cdot \psi_{p j, t}+\alpha_{7} f\left(\Omega_{p j, t}\right)+\alpha_{8} Z_{p}+\varepsilon_{p t}
\end{aligned}
$$

where $\tau_{p j, t}$ is the average effective tax rate for tax category $\mathrm{j}$ in province $p$ in year $t, \psi_{p j, t}$ is the equalization-base effect and $\Theta_{p j, t}$ is the equalization-rate effect. Previous studies, such as Boadway and Hayashi, Esteller-Moré and Solé-Ollé, and Smart, ${ }^{46}$ also used average effective tax rates as dependent variables. $D$ is an indicator variable that is equal to one if the province is a non-receiving province in the year, or zero otherwise. We control for this indicator variable as our focus is on the incentive effects of grants on the recipient provinces' tax policy. $Z$ contains all other relevant control variables.

As we have indicated previously, the Canadian federal government provides equalization grants using a formula that is based on the per capita fiscal capacity of the province and that of the standard provinces. For any revenue category, a province with a fiscal capacity that is below the standard fiscal capacity is entitled to receive equalization grants. Since the fiscal capacity of the province is basically determined by its tax base, it is directly related to the tax policy of the recipient government. This shows that the equalization-grant entitlements are endogenous. A number of previous studies also argue that empirical analysis of the effects of grants on fiscal outcomes should consider grants as endogenous. Previous studies such as Knight, Buettner, and Dahlberg et al. ${ }^{47}$ explain in detail why grants in studies such as ours can be endogenous.

As the equalization-grant formula shows a discontinuity in the relationship between equalization-grant entitlement and fiscal capacity, following Buettner, ${ }^{48}$ we rely on this discontinuity to identify the effects of grants on tax rates. As we discussed before, both the equalization-rate and equalization-base effects depend on the relative fiscal capacity of the province. Since the relative fiscal capacity of the province - the ratio of the per capita tax base of a province to the per capita tax base of standard provinces - can have a direct effect on tax-rate choices, we need to control for this element of the equalization-grant formula to identify the exogenous effects of our key variables of interest on tax policy. In order to achieve this, we need to control for a smooth non-linear function of relative fiscal capacity related to the tax category. In Equation (7), $f(\Omega)$ denotes this non-linear function of relative fiscal capacity, $\Omega$. In the empirical analysis, we use various smooth polynomial and spline forms of relative fiscal capacity.

${ }^{46}$ R. Boadway and M. Hayashi, "An Evaluation of the Stabilization Properties of Equalization in Canada," Canadian Public Policy 30 (2004): 91-109; Esteller-Moré and Solé-Ollé, "An empirical analysis”; Smart, "Raising taxes."

47 B. Knight, "Endogenous federal grants and crowd-out of state government spending: Theory and evidence from the federal highway aid program," American Economic Review 92 (2002): 71-92; Buettner, "The Incentive Effect"; Dahlberg et al., "Using a discontinuous."

48 Buettner, "The Incentive Effect." 
Our empirical analysis is based on panel data from all the 10 provinces. We use equalization entitlements related to the two tax categories rather than actual equalization grants in our analysis of tax policy incentives. During the period under consideration, Alberta and Ontario did not receive any equalization grants. British Columbia, Saskatchewan and Newfoundland also did not receive equalization grants in some years. In order to capture the incentive effects of equalization grants only for receiving provinces, we include, $D$, a dummy variable that is equal to one if the province does not receive equalization grants. Then, we control for the interaction terms between this dummy variable and the equalization-rate and -base effects.

In the empirical specification of Equation (7), our key coefficients of interest are $\alpha_{2}$ and $\alpha_{3}$. These coefficients capture the equalization-rate and -base effects for recipient provinces, respectively. While the coefficient estimates shed light on the direction of the equalization incentive effects on tax policy, the numerical magnitude of the coefficients do not have straightforward interpretations. The theoretical model suggests that, for grant recipients, the equalization-rate effect $\left(\Theta_{p j, t}\right)$ has a positive effect on tax rates provided that the province's fiscal capacity is lower than that of the standard provinces. Thus, we expect that $\alpha_{2}>0$. A positive and statistically significant coefficient estimate for $\alpha_{2}$ can be considered as evidence of presence of the equalization-rate effect. As we have indicated previously, this effect is important for large equalization-grant recipient provinces such as Quebec, but less so for smaller Atlantic provinces. So, in the empirical analysis, the equalization-rate effect may be strongly influenced by Quebec. ${ }^{49}$ We also anticipate the equalization-rate effect to be particularly important for business income taxes as provinces generally tend to compete to attract businesses to their jurisdictions. For non-receiving provinces, one can obtain the equalization-rate effect as $\left(\alpha_{2}+\alpha_{5}\right)$. According to the simple theoretical framework, we also expect that $\alpha_{3}>0$. That is, the equalization grant provides an incentive for a recipient province to raise its tax rate through the equalization-base effect $\left(\psi_{p j, t}\right)$. Unlike the equalization-rate effect, the equalization-base effect is important for all receiving provinces. In addition, for all provinces, the personal income tax base is larger than the business income tax base. As a result, we anticipate the equalization-base effect to be stronger for personal income tax.

As in Smart, ${ }^{50}$ we include the weighted-average (weighted by population) average effective tax rate of other provinces as a control variable. This variable enters as a one-period lagged variable, as tax competition literature suggests that normally governments need some time to adjust their tax policies in response to the policy changes of their neighbours. We also control for various economic, demographic and political variables that capture the expenditure needs of the government. More specifically, as in Smart, ${ }^{51}$ we control for the share of the population that is 65 years of age and above ("Old"), the share of the population that is below 20 years of age ("Young"), and the unemployment rate. We also include non-equalization grants as an additional co-variate.

\footnotetext{
49 We conduct a sensitivity analysis to check if the results are robust to the exclusion of Quebec from the analysis.

50 Smart, "Raising taxes."

51 ibid.
} 
It is well known that a tax policy decision is often influenced by the political ideology of the governing party. Left-leaning governments generally have a tendency to raise income tax rates. Thus, we capture this ideological effect on tax policy by including a dummy variable that is equal to one if the premier of the province belongs to the Liberal party or the New Democratic Party (NDP), which are the centre-left political parties in Canada. The literature on elections and fiscal policy indicate that governments may adjust their tax policy to improve their chances of re-election. We control for this possibility by including a dummy variable that is equal to one if there is an election in the following year in our set of control variables.

\section{Data}

In our empirical analysis, we use administrative data obtained from Finance Canada. The administrative dataset includes raw data used to calculate equalization entitlements for each province and revenue category. These data are used to compute the average effective business income tax rate as the ratio of tax revenue to tax base. The average effective personal income tax rate is also calculated as the ratio of the administrative personal income tax revenue data used in the equalization allocation formula to provincial taxable income. The administrative data are also used to calculate the national standard average tax rate as the sum of provincial revenue divided by the sum of tax bases for business income tax. We also use the same dataset to compute per capita tax base of standard provinces as the sum of the tax bases in the five-standard (or 10, as the case may be) provinces by the sum of the population of the standard provinces.

The equalization-base-effect and the equalization-rate-effect variables require information on the national standard average tax rate, the population share of the standard province (relative to the total population of the standard provinces) and the own semi-elasticity estimates. For business income tax, data on the national standard average tax rates are obtained from Finance Canada as indicated above. For personal income tax, we compute the national standard average tax rate using administrative personal income tax revenue data used in the equalization allocation formula and provincial taxable income as the tax base. The data set on provincial taxable income was obtained from various issues of Income Statistics (formerly Tax Statistics on Individuals) published by the Canada Revenue Agency. The data for the various federal grants to provincial governments and tax bases are obtained from the same dataset. Annual provincial data on personal income, GDP deflator, population, unemployment rate, and the number of new immigrants, comes from Statistics Canada database (CANSIM). The data on governing political parties and elections are from the Canadian Parliamentary Guide. The own semi-elasticity estimates are obtained from Dahlby and Ferede. ${ }^{52}$ Their preferred own semielasticity estimates for the corporate income and personal income taxes were -3.671 and -0.762 , respectively. We use these estimated semi-elasticity values to compute the equalizationbase effects for business income and personal income taxes, respectively. ${ }^{53}$ The equalizationrate-effect variable is also computed using the tax-base data obtained from Finance Canada. Table 1a provides summary statistics for the various variables used in our tax-rate regressions.

52 B. Dahlby and E. Ferede, "The effects of tax rate changes on tax bases and the marginal cost of public funds for provincial governments," International Tax and Public Finance 19 (2012): 844-883.

53 Notice that since the own semi-elasticity estimates are constant (and the same for all provinces), they simply scale the equalization-base effects. The underlying results would not change if one prefers not to use elasticity estimates as in Dahlby and Warren, "The fiscal incentive." 
TABLE 1A: SUMMARY STATISTICS FOR VARIABLES IN THE TAX-RATE REGRESSIONS, 1981-2008

\begin{tabular}{|c|c|c|c|c|}
\hline Variables & Mean & $\begin{array}{l}\text { Standard } \\
\text { Deviation }\end{array}$ & Min. & Max. \\
\hline \multicolumn{5}{|l|}{ Business Income Tax } \\
\hline Average effective business income tax rate (in \%) & 11.56 & 7.47 & 3.29 & 78.07 \\
\hline Per capita virtual grants & 286.20 & 153.77 & 34.07 & 574.03 \\
\hline Equalization-rate effect (in \%) & -0.26 & 4.04 & -21.75 & 7.56 \\
\hline Equalization-base effect (in \%) & 32.20 & 8.39 & 13.48 & 48.19 \\
\hline Relative fiscal capacity & 0.81 & 0.49 & 0.10 & 3.81 \\
\hline $\begin{array}{l}\text { Lagged average effective business income tax rate } \\
\text { of other provinces (in \%) }\end{array}$ & 10.26 & 2.07 & 6.30 & 15.31 \\
\hline \multicolumn{5}{|l|}{ Personal Income Tax } \\
\hline Average effective personal income tax rate (in \%) & 8.72 & 1.80 & 5.60 & 16.24 \\
\hline Per capita virtual grants & $1,212.30$ & 429.12 & 393.02 & $2,343.77$ \\
\hline Equalization-rate effect (in \%) & 0.09 & 1.64 & -5.64 & 4.19 \\
\hline Equalization-base effect (in \%) & 6.23 & 1.34 & 2.99 & 9.08 \\
\hline Relative fiscal capacity & 0.89 & 0.15 & 0.55 & 1.35 \\
\hline $\begin{array}{l}\text { Lagged average effective personal income tax rate } \\
\text { of other provinces }(\%)\end{array}$ & 9.17 & 1.41 & 6.93 & 12.68 \\
\hline \multicolumn{5}{|l|}{ Other Control Variables } \\
\hline Per capita non-equalization grants (other grants) & 619.48 & 173.19 & 308.44 & $1,113.62$ \\
\hline Share of population 65 years and above (Old) (in \%) & 12.16 & 1.82 & 7.15 & 15.38 \\
\hline Share of population below 20 years (Young) (in \%) & 28.04 & 3.37 & 21.47 & 40.31 \\
\hline Dummy variable for left-leaning provincial government (Left) & 0.50 & 0.50 & 0.00 & 1.00 \\
\hline Dummy variable for the election year (Election) & 0.27 & 0.45 & 0.00 & 1.00 \\
\hline Unemployment rate (in \%) & 10.01 & 3.81 & 3.40 & 20.20 \\
\hline
\end{tabular}

Note: For lagged average effective tax rate of other provinces, the number of observations is 270; for all others it is 280 .

\section{Empirical results and discussions}

In this section, we present the empirical analysis related to the effects of equalization grants on business income and personal income tax policy incentives. While Table 2 presents the regression results for business income tax, the corresponding results for personal income tax are shown in Table 3. All regressions control for provincial fixed effects, province-specific time trends and non-linear form of relative fiscal capacity, as indicated, but we do not report their coefficient estimates for the sake of brevity. Note also that the result tables provide standard errors that are robust to heteroskedasticity and autocorrelation 
TABLE 2: BUSINESS INCOME TAX REGRESSION, 1981-2008

\begin{tabular}{|c|c|c|c|c|c|c|}
\hline & (1) & (2) & (3) & (4) & (5) & (6) \\
\hline Virtual grant & $\begin{array}{c}-0.0218^{* *} \\
(0.00995)\end{array}$ & $\begin{array}{c}-0.02011^{* *} \\
(0.00871)\end{array}$ & $\begin{array}{c}-0.0242 * * \\
(0.00982)\end{array}$ & $\begin{array}{c}-0.0260 * * * \\
(0.00984)\end{array}$ & $\begin{array}{c}-0.0199 * * \\
(0.00930)\end{array}$ & $\begin{array}{l}-0.0260 * * \\
(0.0100)\end{array}$ \\
\hline Rate effect & $\begin{array}{l}-0.248 \\
(0.362)\end{array}$ & $\begin{array}{r}-0.270 \\
(0.327)\end{array}$ & $\begin{array}{l}-0.461 \\
(0.451)\end{array}$ & $\begin{array}{r}-0.536 \\
(0.378)\end{array}$ & $\begin{array}{l}-0.236 \\
(0.442)\end{array}$ & $\begin{array}{r}-0.594 \\
(0.431)\end{array}$ \\
\hline Base effect & $\begin{array}{c}0.247^{* * *} \\
(0.0662)\end{array}$ & $\begin{array}{c}0.216 \text { *** } \\
(0.0685)\end{array}$ & $\begin{array}{l}0.371 \text { ** } \\
(0.178)\end{array}$ & $\begin{array}{l}0.381 \text { ** } \\
(0.177)\end{array}$ & $\begin{array}{c}0.347 * \\
(0.180)\end{array}$ & $\begin{array}{l}0.383 \text { ** } \\
(0.177)\end{array}$ \\
\hline Non-receiving (Non) & $\begin{array}{r}-3.273 \\
(4.844)\end{array}$ & $\begin{array}{l}-9.3944^{* *} \\
(4.155)\end{array}$ & $\begin{array}{r}-1.703 \\
(5.938)\end{array}$ & $\begin{array}{l}-8.597 * \\
(4.855)\end{array}$ & $\begin{array}{r}-0.957 \\
(6.248)\end{array}$ & $\begin{array}{r}-7.052 \\
(4.936)\end{array}$ \\
\hline Non-X rate effect & $\begin{array}{r}-0.490 \\
(0.297)\end{array}$ & $\begin{array}{r}0.151 \\
(0.300)\end{array}$ & $\begin{array}{r}-0.415 \\
(0.466)\end{array}$ & $\begin{array}{r}0.532 \\
(0.433)\end{array}$ & $\begin{array}{r}-0.885 \\
(0.636)\end{array}$ & $\begin{array}{r}0.341 \\
(0.410)\end{array}$ \\
\hline Non-X base effect & $\begin{array}{c}0.173 \text { * } \\
(0.101)\end{array}$ & $\begin{array}{l}0.317 \text { *** } \\
(0.120)\end{array}$ & $\begin{array}{r}0.152 \\
(0.121)\end{array}$ & $\begin{array}{l}0.299 * * \\
(0.124)\end{array}$ & $\begin{array}{r}0.148 \\
(0.121)\end{array}$ & $\begin{array}{l}0.280 \text { ** } \\
(0.117)\end{array}$ \\
\hline Other provinces' tax rate & & & $\begin{array}{r}-0.228 \\
(0.421)\end{array}$ & $\begin{array}{r}-0.406 \\
(0.370)\end{array}$ & $\begin{array}{r}-0.0801 \\
(0.471)\end{array}$ & $\begin{array}{r}-0.347 \\
(0.384)\end{array}$ \\
\hline Other grants a & & & $\begin{array}{r}0.00650 \\
(0.00587)\end{array}$ & $\begin{array}{r}0.00486 \\
(0.00473)\end{array}$ & $\begin{array}{r}0.00667 \\
(0.00610)\end{array}$ & $\begin{array}{r}0.00564 \\
(0.00521)\end{array}$ \\
\hline Old & & & $\begin{array}{r}1.334 \\
(1.541)\end{array}$ & $\begin{array}{r}1.681 \\
(1.555)\end{array}$ & $\begin{array}{r}1.331 \\
(1.519)\end{array}$ & $\begin{array}{r}1.630 \\
(1.581)\end{array}$ \\
\hline Young & & & $\begin{array}{r}1.299 \\
(1.033)\end{array}$ & $\begin{array}{l}2.321 * \\
(1.211)\end{array}$ & $\begin{array}{r}0.795 \\
(0.909)\end{array}$ & $\begin{array}{c}2.161 \text { * } \\
(1.220)\end{array}$ \\
\hline Left & & & $\begin{array}{r}0.218 \\
(1.275)\end{array}$ & $\begin{array}{r}0.326 \\
(1.242)\end{array}$ & $\begin{array}{r}0.239 \\
(1.299)\end{array}$ & $\begin{array}{r}0.324 \\
(1.261)\end{array}$ \\
\hline Election & & & $\begin{array}{r}-0.345 \\
(1.022)\end{array}$ & $\begin{array}{r}-0.282 \\
(0.943)\end{array}$ & $\begin{array}{r}-0.308 \\
(1.082)\end{array}$ & $\begin{array}{r}-0.306 \\
(0.980)\end{array}$ \\
\hline Unemployment & & & $\begin{array}{r}-0.404 \\
(0.413)\end{array}$ & $\begin{array}{r}-0.702 \\
(0.470)\end{array}$ & $\begin{array}{r}-0.250 \\
(0.377)\end{array}$ & $\begin{array}{r}-0.660 \\
(0.465)\end{array}$ \\
\hline Relative fiscal capacity & quadratic & cubic & quadratic & cubic & $\begin{array}{l}\text { linear- } \\
\text { spline }\end{array}$ & $\begin{array}{c}\text { quadratic- } \\
\text { spline }\end{array}$ \\
\hline No. of observations & 280 & 280 & 270 & 270 & 270 & 270 \\
\hline Adjusted R-squared & 0.376 & 0.427 & 0.388 & 0.462 & 0.353 & 0.434 \\
\hline
\end{tabular}

Notes: Dependent variable is average effective business tax rate. All regressions include provincial fixed-effects and province-specific time trends. Robust standard errors in parentheses. Significance levels are indicated by *** for one per cent, ** for five per cent, and * for 10 per cent.

a The coefficient is divided by 100 . 
TABLE 3: PERSONAL INCOME TAX REGRESSION, 1981-2008

\begin{tabular}{|c|c|c|c|c|c|c|}
\hline & (1) & (2) & (3) & (4) & (5) & (6) \\
\hline Virtual grant a & $\begin{array}{l}-0.220 * * * \\
(0.0435)\end{array}$ & $\begin{array}{l}-0.221 * * * \\
(0.0437)\end{array}$ & $\begin{array}{l}-0.235^{* * *} \\
(0.0494)\end{array}$ & $\begin{array}{l}-0.257^{* * *} \\
(0.0513)\end{array}$ & $\begin{array}{l}-0.242 * * * \\
(0.0504)\end{array}$ & $\begin{array}{c}-0.251 \text { *** } \\
(0.0509)\end{array}$ \\
\hline Rate effect & $\begin{array}{l}0.985^{* * *} \\
(0.376)\end{array}$ & $\begin{array}{l}0.973 \text { ** } \\
(0.385)\end{array}$ & $\begin{array}{l}1.125^{* * *} \\
(0.374)\end{array}$ & $\begin{array}{l}1.016^{* * *} \\
(0.383)\end{array}$ & $\begin{array}{l}1.089 * * * \\
(0.372)\end{array}$ & $\begin{array}{l}1.007 * * \\
(0.389)\end{array}$ \\
\hline Base effect & $\begin{array}{l}1.477^{* * *} \\
(0.112)\end{array}$ & $\begin{array}{l}1.479 * * * \\
(0.114)\end{array}$ & $\begin{array}{l}1.487^{* * *} \\
(0.112)\end{array}$ & $\begin{array}{l}1.530 * * * \\
(0.118)\end{array}$ & $\begin{array}{l}1.520 * * * \\
(0.110)\end{array}$ & $\begin{array}{l}1.526 * * * \\
(0.119)\end{array}$ \\
\hline Non-receiving (Non) & $\begin{array}{l}2.830 \text { *** } \\
(1.016)\end{array}$ & $\begin{array}{l}2.835 * * * \\
(1.023)\end{array}$ & $\begin{array}{l}1.907 * \\
(0.988)\end{array}$ & $\begin{array}{l}1.995 \text { ** } \\
(1.010)\end{array}$ & $\begin{array}{l}1.978 * * \\
(0.995)\end{array}$ & $\begin{array}{l}2.014 * * \\
(1.016)\end{array}$ \\
\hline Non-X rate effect & $\begin{array}{l}-0.779 * \\
(0.404)\end{array}$ & $\begin{array}{l}-0.772 * \\
(0.406)\end{array}$ & $\begin{array}{r}-0.604 \\
(0.410)\end{array}$ & $\begin{array}{r}-0.539 \\
(0.413)\end{array}$ & $\begin{array}{r}-0.625 \\
(0.446)\end{array}$ & $\begin{array}{r}-0.524 \\
(0.414)\end{array}$ \\
\hline Non-X base effect & $\begin{array}{l}-0.393 \text { ** } \\
(0.161)\end{array}$ & $\begin{array}{l}-0.393^{* *} \\
(0.161)\end{array}$ & $\begin{array}{l}-0.267 * \\
(0.158)\end{array}$ & $\begin{array}{l}-0.267 * \\
(0.158)\end{array}$ & $\begin{array}{l}-0.280 * \\
(0.158)\end{array}$ & $\begin{array}{l}-0.273 * \\
(0.159)\end{array}$ \\
\hline Other provinces' tax rate & & & $\begin{array}{r}-0.0697 \\
(0.0485)\end{array}$ & $\begin{array}{r}-0.0782 \\
(0.0499)\end{array}$ & $\begin{array}{r}-0.0692 \\
(0.0497)\end{array}$ & $\begin{array}{r}-0.0783 \\
(0.0498)\end{array}$ \\
\hline Other grants a & & & $\begin{array}{c}-0.000921 \text { ** } \\
(0.000453)\end{array}$ & $\begin{array}{l}-0.000892^{* *} \\
(0.000450)\end{array}$ & $\begin{array}{l}-0.000811 * \\
(0.000442)\end{array}$ & $\begin{array}{l}0.000897 \text { ** } \\
(0.000452)\end{array}$ \\
\hline Old & & & $\begin{array}{r}0.232 \\
(0.195)\end{array}$ & $\begin{array}{r}0.326 \\
(0.203)\end{array}$ & $\begin{array}{r}0.231 \\
(0.199)\end{array}$ & $\begin{array}{r}0.299 \\
(0.200)\end{array}$ \\
\hline Young & & & $\begin{array}{r}0.194 \\
(0.120)\end{array}$ & $\begin{array}{c}0.231 \text { * } \\
(0.121)\end{array}$ & $\begin{array}{c}0.200 * \\
(0.119)\end{array}$ & $\begin{array}{c}0.219 * \\
(0.122)\end{array}$ \\
\hline Left & & & $\begin{array}{l}0.0583 \\
(0.113)\end{array}$ & $\begin{array}{l}0.0344 \\
(0.114)\end{array}$ & $\begin{array}{l}0.0240 \\
(0.111)\end{array}$ & $\begin{array}{l}0.0361 \\
(0.114)\end{array}$ \\
\hline Election & & & $\begin{array}{r}-0.0406 \\
(0.0904)\end{array}$ & $\begin{array}{r}-0.0417 \\
(0.0911)\end{array}$ & $\begin{array}{r}-0.0419 \\
(0.0911)\end{array}$ & $\begin{array}{r}-0.0424 \\
(0.0912)\end{array}$ \\
\hline Unemployment & & & $\begin{array}{l}-0.122 \text { *** } \\
(0.0391)\end{array}$ & $\begin{array}{l}-0.129 * * * \\
(0.0394)\end{array}$ & $\begin{array}{l}-0.125 * * * \\
(0.0395)\end{array}$ & $\begin{array}{l}-0.128^{* * *} \\
(0.0389)\end{array}$ \\
\hline Relative fiscal capacity & quadratic & cubic & quadratic & cubic & $\begin{array}{l}\text { linear- } \\
\text { spline }\end{array}$ & $\begin{array}{l}\text { quadratic- } \\
\text { spline }\end{array}$ \\
\hline No. of observations & 280 & 280 & 270 & 270 & 270 & 270 \\
\hline Adjusted R-squared & 0.859 & 0.859 & 0.863 & 0.864 & 0.862 & 0.863 \\
\hline
\end{tabular}

Notes: Dependent variable is average effective personal income tax rate. Provincial fixed-effects and province-specific time trends are included in all regressions. Robust standard errors in parentheses. Significance levels are indicated by *** for one per cent, ** for five per cent, and * for 10 per cent.

a The coefficient is divided by 100.

We begin in column (1) of Tables 2 and 3 by estimating our basic regression model with an ordinary least squares (OLS) estimation method. The dependent variables are average effective tax rates and we control for a quadratic form of relative fiscal capacity. Our results show that, as in Buettner, ${ }^{54}$ the virtual grant is negative and statistically significant. This shows that virtual grants have a negative effect on tax rates. The reason is that virtual grants raise the financing capacity of provincial governments and, as a result, enable them to finance any given amount

54 Buettner, "The Incentive Effect." 
of government spending at a lower tax rate. The virtual grant coefficient estimates show the effects of equalization grants on tax rates if the grant system were actually not based on fiscal capacity. If we consider a hypothetical situation where the equalization grants are substituted with block grants that do not depend on recipient provinces' fiscal capacity, a $\$ 100$ per capita increase in such grants is associated with a fall in business and personal income tax rates by about 2.2 and 0.22 percentage points, respectively.

The results in column (1) of tables 2 and 3 also show that, as expected, the equalization-base effect is positive and statistically significant at a five per cent level or better for both regressions. However, the equalization-rate effect is statistically significant only for personal income tax. Thus, the results suggest that equalization grants provide an incentive for provinces to raise the business income tax rate only through the equalization-base effect. For personal income tax, on the other hand, our results indicate that equalization grants affect the tax policy incentives through both equalization-base and -rate effects. The results suggest that a one percentage point increase in the equalization-base effect is associated with a 0.25 and 1.5 percentage point increase in the business and personal income tax rates, respectively. Similar results are also obtained in column (2) when we control for a cubic form of relative fiscal capacity.

In column (3), we control for a quadratic form of relative fiscal capacity and include additional co-variates to capture the effects of economic, demographic, and political factors that potentially influence tax policy. Again, the equalization-base effect continues to be positive and statistically significant for both business income and personal income taxes, while the equalization-rate effect is statistically significant only in the latter.

In column (4), as in column (3), we include all the control variables and use a cubic form of relative fiscal capacity. Based on adjusted R-squared, the regression with cubic specification for fiscal capacity shows the best fit for the data. Our results indicate that in a hypothetical scenario where the equalization grants are substituted with block grants, a $\$ 100$ per capita increase in such grants is associated with a fall in business and personal income tax rates by about 2.6 and 0.26 percentage points, respectively.

The results also show that the equalization-base effect is again positive and statistically significant at the five per cent level or better in both tax-rate regressions. However, the equalization-rate effect is again not statistically significant for business income tax, but it is statistically significant at five per cent level for personal income tax. Thus, the empirical results indicate that, for business income tax, the effects of equalization grants on businessincome-tax policy incentive works through the tax-base effect. For personal income tax, however, both the equalization-base and -rate effects seem to be important in influencing the tax policy incentives. ${ }^{55}$ The regression results suggest that a one percentage point increase in the equalization-base effect is associated with 0.38 percentage point increase in the business income tax rate and a 1.5 percentage point increase in the personal income tax rate. Thus, our results are consistent with the widely held view that the Canadian equalization system provides the recipient provinces the incentive to raise their tax rates.

55 Partly because of the federal government's Quebec abatement program, personal income tax rates in Quebec are generally higher than those of other provinces. Thus, one may wonder if the statistical significance of the equalizationrate effect in only the personal income tax rate regressions is driven by Quebec. As the sensitivity analysis in the following section reveals, the statistical significance of the equalization-rate effect disappears once we exclude Quebec. Thus the equalization-rate effect in the personal income tax rate regression may indeed be driven by Quebec. 
So far, we rely on using polynomial specifications for relative fiscal capacity. However, theoretically, other forms of smooth functional forms can also be employed. To check if our main result that equalization grants affect tax policy incentives is robust to other forms of specification, in columns (5) and (6), we control for linear-spline and quadratic-spline form of relative fiscal capacity, respectively. The results are qualitatively similar to what we found before, suggesting that the results are robust to the form of non-linear function of relative fiscal capacity. In general, our results suggest that equalization grants provide recipient provincial governments an incentive to raise their business income and personal income tax rates. Thus, the results provide empirical support to the hypothesis that equalization grants provide an incentive to recipient governments to raise tax rates. And we find that this incentive effect works through the equalization-base effect for business income tax and through both equalization-base and -rate effects for personal income tax. That is, when provincial governments raise their income tax rates, their tax bases fall and this increases the amount of equalization entitlements. Dahlby and Warren $^{56}$ find similar results for Australia.

\section{Robustness checks}

We conduct a sensitivity analysis to check the robustness of our preferred regression results of tables 2 and 3. The results are shown in Table 4 below.

\section{TABLE 4: SENSITIVITY ANALYSIS}

\begin{tabular}{|c|c|c|c|c|c|c|}
\hline & \multicolumn{3}{|c|}{ Business Income Tax } & \multicolumn{3}{|c|}{ Personal Income Tax } \\
\hline & (1) & (2) & (3) & (4) & (5) & (6) \\
\hline & $\begin{array}{c}\text { Five- } \\
\text { province } \\
\text { Standard }\end{array}$ & $\begin{array}{l}\text { Excluding } \\
\text { Quebec }\end{array}$ & $\begin{array}{l}\text { Controlling } \\
\text { for Tax } \\
\text { Interactions }\end{array}$ & $\begin{array}{c}\text { Five- } \\
\text { province } \\
\text { Standard }\end{array}$ & $\begin{array}{l}\text { Excluding } \\
\text { Quebec }\end{array}$ & $\begin{array}{l}\text { Controlling } \\
\text { for Tax } \\
\text { Interactions }\end{array}$ \\
\hline Virtual grants & $\begin{array}{l}-0.0228 * * \\
(0.0102)\end{array}$ & $\begin{array}{l}-0.0265 \text { ** } \\
(0.0104)\end{array}$ & 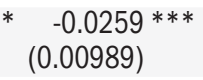 & $\begin{array}{c}-0.00413 \text { *** } \\
(0.000682)\end{array}$ & $\begin{array}{l}-0.00185^{* * *} \\
(0.000474)\end{array}$ & $\begin{array}{l}-0.00262 * * * \\
(0.000531)\end{array}$ \\
\hline Rate effect & $\begin{array}{l}-1.086 * * \\
(0.501)\end{array}$ & $\begin{array}{r}-0.212 \\
(0.940)\end{array}$ & $\begin{array}{r}-0.530 \\
(0.383)\end{array}$ & $\begin{array}{r}0.522 \\
(0.458)\end{array}$ & $\begin{array}{r}-0.258 \\
(0.550)\end{array}$ & $\begin{array}{l}1.011 \text { *** } \\
(0.384)\end{array}$ \\
\hline Base effect & $\begin{array}{r}0.299 \\
(0.188)\end{array}$ & $\begin{array}{l}0.394 \text { ** } \\
(0.188)\end{array}$ & $\begin{array}{l}0.379 * * \\
(0.171)\end{array}$ & $\begin{array}{l}1.476 * * * \\
(0.118)\end{array}$ & $\begin{array}{c}1.335 * * * \\
(0.0761)\end{array}$ & $\begin{array}{l}1.539 * * * \\
(0.121)\end{array}$ \\
\hline No. of observations & 250 & 243 & 270 & 250 & 243 & 270 \\
\hline Adjusted R-squared & 0.494 & 0.433 & 0.460 & 0.878 & 0.810 & 0.864 \\
\hline
\end{tabular}

Notes: Dependent variable is average effective tax rate. The robustness checks are conducted based on our preferred regression results of column (4) of Tables 3 and 4 and we use the same set of control variables used in the preferred regressions. Robust standard errors in parentheses. Significance levels are indicated by *** for one per cent, ** for five per cent, and * for 10 per cent. Provincial fixed-effects, province-specific time trends and all other control variables are included but not reported.

56 Dahlby and Warren, "The fiscal incentive." 
During the period under consideration, the number of standard provinces change from 10 provinces to five provinces, and more recently, back to 10 provinces. To check if this change in the number of standard provinces influences our results, we do the analysis only for the period where the five-province standard was in place. As results in columns (1) and (4), our results are robust to the change in the number of standard provinces.

As compared to other provinces, Quebec has various unique fiscal features. For example, it is the only province that receives the federal tax abatement. It is also the largest of all the equalization-grant recipient provinces, and as such, we expect the equalization-rate effect to be stronger and more relevant for the province. In columns (2) and (5), we exclude Quebec from our analysis. The results show that, while the virtual grants and the equalization-base effects continue to be statistically significant with their respective expected signs, the equalization-rate effect is now insignificant in the personal income tax-rate regression.This suggests that the statistical significance of the equalization-rate effect in the personal income tax regression that we find in the previous section is driven by Quebec.

As previous studies indicate, business and personal income tax rates are related in many ways and may influence each other. Thus, one may suspect that personal income tax rate may influence the incentive effects of business income tax rate and vice versa. To capture this, we include the personal income tax rate and the business income tax rate as additional control variables in columns (3) and (6), respectively. Again, our results are robust to this sensitivity check.

In sum, our empirical analysis provides empirical evidence that the Canadian equalization system influences recipient provinces tax policy incentives. These incentive effects seem to work mainly through the equalization-base effect. The results also show that virtual grants have statistically significant negative effects on tax rates. The policy implication of this is that if the current equalization grants are substituted with block grants that are not related to the fiscal capacity of the provinces, provincial tax rates will be lower.

\section{EQUALIZATION GRANTS AND GOVERNMENT EXPENDITURE}

\section{Empirical specification and methodology}

We now examine the effects of equalization grants on the level and composition of provincial expenditures. In the previous section, we have seen that equalization grants provide receiving provinces an incentive to raise their tax rates, which in turn, affects their tax base and the amount of equalization-grant entitlements. Provincial expenditures may also have the power to influence the tax bases of provinces, which in turn affects their equalization grants. In fact, theoretical studies, such as Dahlby, ${ }^{57}$ and Cyrenne and Pandey, ${ }^{58}$ show that equalization grants can affect both the level and the composition of government expenditure. Equalization grants may influence provincial governments to spend less on tax-base-enhancing expenditures and more on consumptive expenditures. Thus, the composition of provincial expenditure can be

\footnotetext{
57 Dahlby, "The Incentive Effects."

58 Cyrenne and Pandey, "Fiscal equalization."
} 
influenced by equalization grants. The literature on the flypaper effects also show that lumpsum grants, such as equalization grants, can stimulate receiving jurisdictions' expenditure. See Gamkhar and $\mathrm{Shah}^{59}$ and the references contained therein. Thus, equalization grants can influence both the level and composition of provincial spending.

In order to analyze the effect of equalization grants on the level and composition of provincial spending, we use the following basic specification:

$$
E_{p, t}=\beta_{0}+\beta_{1} G_{p, t}+\beta_{2} X+u_{p, t}
$$

where $E_{p, t}$ is the real per capita total (or category of) government expenditure in province $p$ in year $t, G_{p, t}$ is real per capita equalization grants, and $X$ contains all other relevant control variables. Note that, due to the variation in local government expenditure responsibilities and the corresponding differences in provincial governments' own expenditures, we have used consolidated provincial and local spending as the dependent variable in our regression models. Empirical specifications similar to Equation (8) are quite commonly used in the literature. Our empirical specification is very close to that of Shelton..$^{60}$ Mauro ${ }^{61}$ also analyzed the impact of corruption on the composition of government expenditure, however he used government spending as a ratio of GDP as a dependent variable. Notice that our empirical methodology in this section is different than what we employed in the previous section, as it is not feasible to construct virtual grants for the total equalization grants and decompose the equalization-grant effects into income and incentive effects. It is also important to note that we use actual equalization grants rather than equalization entitlements associated with a specific tax category as we did in the previous section. As a result of this, the empirical methodology employed in this section is different than what we use in the tax policy incentive analysis.

In addition to the total provincial expenditure, we examine the effects of equalization grants on 12 provincial expenditure categories. ${ }^{62}$ These categories include government expenditure on: health services ("Health"), education ("Education"), social services ("Social"), transportation and communication ("TransComm"), resource conservation and industrial assistance ("Resource"), protection of persons and property ("Protection"), general government services ("Government services"), environment ("Environment"), recreation and culture ("Recreation"), housing ("Housing"), regional planning and development ("Regional"), and labour, employment and immigration ("Labour and immigration"). Cyrenne and Pandey ${ }^{63}$ also study the effect of equalization grants on expenditure compositions by dividing expenditure into two broad categories (i.e., productive or unproductive), rather than studying each individual category as we do in this paper. Although such classification simplifies empirical analysis, it is clear that each expenditure category may include both productive and unproductive spending elements.

\footnotetext{
59 Gamkhar and Shah, "The impact."

60 C. A. Shelton, "The Size and composition of government expenditure," Journal of Public Economics 91 (2007): 2230-2260.

61 P. Mauro, "Corruption and the composition of government expenditure," Journal of Public Economics 69 (1998): 263-279.

62 While the expenditure categories are disaggregated, it is important to note that they are sufficiently broad so that spending within a given category could include both tax-base-enhancing and consumption elements. This problem also equally applies even to those studies that arbitrarily classify spending categories as productive or nonproductive.

63 Cyrenne and Pandey, "Fiscal equalization."
} 
We focus on analyzing levels of per capita spending rather than shares of spending for various reasons. First, in many policy debates, various commentators and analysts often compare provinces on the basis of spending per capita rather than spending shares. So our analysis helps shed light on how equalization grants affect the various spending categories on per capita basis. Second and most importantly, in the flypaper literature, the debate on the stimulative effects of lump-sum grants on subnational governments' spending focuses on the response of per capita expenditure to grants. See Dahlberg et al. and the references contained therein. ${ }^{64}$ Thus, we use a similar approach to make our results comparable to the wider flypaper literature.

In Equation (8), our main coefficient of interest is $\beta_{1}$. Regarding the effects of grants on government spending, the literature on flypaper effects suggest that lump-sum intergovernmental grants, such as equalization grants, have a stimulative effect on government spending. Thus we expect $\beta_{1}>0$ in the total government expenditure equation.

Theoretical studies on the incentive effects of equalization grants on government spending suggest that equalization grants may give provincial governments the incentive to spend more on consumptive spending and less on productive services that have the potential to increase their tax bases. See Dahlby, and Cyrenne and Pandey. ${ }^{65}$ If this is indeed the case, we expect equalization grants to affect provincial spending on such tax-base-enhancing services as education, transportation and communication to be negative.

We include various economic, demographic and political co-variates as control variables. The economic variables included in our regressions are per capita personal income as in Winer ${ }^{66}$ and Gamkhar and Oates. ${ }^{67} \mathrm{We}$ also control for the unemployment rate and non-equalization grants.

The demographic makeup of a province can influence both the total amount and the type of public services to be provided. Aging and young populations in particular necessitate various social and health-care related spending by the government. To account for this, as in Dahlberg et al., ${ }^{68}$ we include the shares of the population that are 65 years and above and below 20 years of age as control variables. We also include the share of the population comprised of new immigrants to the province as an additional co-variate.

A government's spending decision and the composition of government spending can often be influenced by the political ideology of the governing party and presence of an election. ${ }^{69}$ As discussed in Baker et al., ${ }^{70}$ Kneebone and McKenzie, ${ }^{71}$ and others, left-leaning governments

${ }^{64}$ Dahlberg et al., "Using a discontinuous."

65 Dahlby, "The Incentive Effects"; Cyrenne and Pandey, "Fiscal equalization."

66 Winer, "Some evidence."

67 S. Gamkhar and W. Oates, "Asymmetries in the response to increases and decreases in intergovernmental grants: some empirical findings," National Tax Journal 49 (1996): 501-512.

68 Dahlberg et al., "Using a discontinuous."

69 See: A. Brender and A. Drazen, "Elections, leaders, and the composition of government spending," Journal of Public Economics 97 (2013): 18-31.

70 M. Baker, A. Payne and M. Smart, “An empirical study of matching grants: 'the cap on CAP,'” Journal of Public Economics 72 (1999): 269-288.

71 R. Kneebone and K. McKenzie, "Electoral and Partisan Cycles in Fiscal Policy: An Examination of Canadian Provinces," International Tax and Public Finance 8 (2001): 753-774. 
generally have a tendency to be pro-spending. Thus, we further expand our set of control variables to capture this ideological effect on government spending. We include a dummy variable ("Left") that is equal to one if the premier of the province belongs to the Liberal party or the New Democratic Party (NDP). We also include an election dummy variable that is equal to one in the years in which there is an election.

As discussed previously, the allocation of equalization grants is based on a formula that compares the per capita fiscal capacity of the province and that of the standard provinces. While provinces with fiscal capacities below the standard fiscal capacity receive equalization grants, those provinces with fiscal capacities above the standard do not receive grants. Since the fiscal capacity of the province determines the revenue-generation capacity of the province, it can have a direct effect on government spending. This shows that the equalization grants are endogenous. A number of previous studies also argue that empirical analysis of the effects of grants on government spending should consider grants as endogenous. ${ }^{72}$ Thus, the basic government expenditure specification of Equation (8) cannot be estimated consistently using ordinary least squares since our key variable of interest, equalization grants, is endogenous. Instead, as in previous similar studies, we rely on the Instrumental Variable (IV) estimation method for our empirical analysis. We discuss below the choice of instruments and our main identification strategy.

In order to analyze the effect of equalization grants on the level and composition of provincial spending, we focus on total equalization grants rather than equalization entitlements related to a particular revenue category as we did in the previous section. The total equalization grant to be provided for a province is determined by adding all the equalization-grant entitlements from the various revenue categories. Using Equation (2a) of the previous section, for all different tax revenue categories, the total per capita equalization-grant entitlement for a province is calculated using the following formula:

$$
G_{p}=\sum_{j=1}^{n} g_{p j}=\sum_{j=1}^{n} \bar{\tau}_{j}\left(\bar{B}_{j}-B_{p j}\right) .
$$

If the total entitlement for all revenue categories, as shown in Equation (9), is positive, then the province is categorized as a receiving province and receives per capita equalization grants $G_{p}$. Thus, provinces with a below-average measure of fiscal capacity receive equalization grants to bring them up to the national average. However, if the difference from the formula in Equation (9) is negative, it means that the province has a fiscal capacity better than the national average and is not entitled to receive equalization payments.

Note that Equation (9) shows that there is a discontinuity in the equalization-grant allocation formula. As the equalization-grant formula shows a discontinuity in the relationship between grants and fiscal capacity, we rely on this discontinuity to identify the effects of equalization grants on government spending. Thus, as in Dahlberg et al., ${ }^{73}$ we use the equalization-grant

\footnotetext{
72 See, for instance: Knight, "Endogenous federal”; Dahlberg et al., "Using a discontinuous"; and L. Brooks, J. Phillips and M. Sinitsyn, "The cabals of a few or the confusion of a multitude: the institutional trade-off between representation and governance," American Economic Journal: Economic Policy 3 (2011): 1-24.

73 Dahlberg et al., "Using a discontinuous."
} 
formula, denoted as "Formula," as the excluded instrument for grants. ${ }^{74}$ Angrist and Lavy ${ }^{75}$ also use the class-size allocation formula as an instrument for class size conditional on a smooth function of enrollment. Since the fiscal capacity of the province can have a direct effect on government spending, we need to control for this element of the equalization-grant formula. We use a smooth polynomial function of fiscal capacity. Our basic identifying assumption is that any other effect of the formula on government expenditure is controlled by the smooth function of fiscal capacity of the province.

\section{Data}

The dataset for our empirical analysis come from various sources. Annual provincial and local government expenditures, personal income, prices, population and the number of new immigrants come from Statistics Canada database (CANSIM). The data source for all other variables are as indicated before. Table $1 \mathrm{~b}$ presents the summary statistics for the various variables used in the government-expenditure regressions.

TABLE 1B: SUMMARY STATISTICS FOR VARIABLES IN GOVERNMENT-EXPENDITURE REGRESSIONS, 1981-2008

\begin{tabular}{|l|r|r|r|r|}
\hline Variables & Mean & \multicolumn{1}{|c|}{$\begin{array}{c}\text { Standard } \\
\text { Deviation }\end{array}$} & Min. & Max. \\
\hline Government Expenditure and Its Components & & & & 12,191 \\
Total expenditure & 8,601 & 1,320 & 5,619 & 3,725 \\
Health services & 2,083 & 521 & 1,122 & 5,061 \\
Education & 1,911 & 377 & 1,189 & 2,793 \\
Social services & 1,077 & 383 & 553 & 1,339 \\
Transportation and communications & 627 & 146 & 360 & 1,945 \\
Resource conservation and industrial assistance & 472 & 306 & 108 & 671 \\
Protection of persons and property & 427 & 93 & 193 & 770 \\
General government services & 311 & 106 & 125 & 439 \\
Environment & 239 & 76 & 68 & 406 \\
Recreation and culture & 221 & 71 & 92 & 207 \\
Housing & 76 & 44 & 0 & 207 \\
Regional planning and development & 53 & 23 & 0 & 107 \\
Labour, employment and immigration & 27 & 21 & 0 & \\
Other Variables ${ }^{\text {a }}$ & & & & \\
Equalization grants & 819 & 715 & 0 & 2,395 \\
Tax yield of provinces ${ }^{b}$ & 4,576 & 1,927 & 1,320 & 12,839 \\
Personal income & 23,878 & 3,981 & 14,282 & 33,879 \\
Other grants & 710 & 128 & 354 & 931 \\
Population share of new immigrants (in \%) & 0.41 & 0.33 & 0.05 & 1.37 \\
\hline
\end{tabular}

Note: All monetary values are per capita in 2002 Canadian dollars. For all variables the number of observations is 280. Government expenditure data are consolidated provincial and local (in fiscal year).

a See also Table 1a for other control variables

$b$ Fiscal capacity is measured by the tax yield of provinces as in the equalization-grant allocation formula used by the federal government. This is simply the sum of the various provincial tax bases evaluated at their respective national average tax rates.

74 The instrument is defined as: Formula
where the variables are as defined before. $\left(\frac{\sum_{j=1}^{n} \bar{\tau}_{j} \bar{B}_{j}}{\sum_{j=1}^{n} \tau_{j} B_{p j}}-1\right)$

75 J. D. Angrist and V. Lavy, "Using Maimonides' rule to estimates the effect of class size on scholastic achievement," Quarterly Journal of Economics 114 (1999): 533-575. 


\section{Empirical results and discussions}

We begin the discussion of our empirical results by presenting the first-stage results in Table 5 . Columns (1) to (4) show the regression results associated with various non-linear specifications of relative fiscal capacity. We can check the relevance of the excluded instrument, Formula, by looking at the $\mathrm{t}$-value of the instrument. The results suggest that the instrument for equalization grant is positive and statistically significant in all cases. Various statistical tests also confirm the relevance of our excluded instrument. More specifically, our empirical model is not underidentified as the null hypothesis of under-identification is rejected at the five per cent significance level for all regressions. Furthermore, the Kleibergen-Paap F-statistics for weakinstruments bias indicates that the results are not affected by the presence of weak instruments. Thus, we conclude that our instrument for equalization grants is statistically valid.

\section{TABLE 5: FIRST-STAGE REGRESSIONS, 1981-2008}

\begin{tabular}{|c|c|c|c|c|}
\hline Variable & (1) & (2) & (3) & (4) \\
\hline Income & $\begin{array}{l}0.0744 \text { *** } \\
(0.0257)\end{array}$ & $\begin{array}{l}0.0647^{* * *} \\
(0.0230)\end{array}$ & $\begin{array}{l}0.0628 * * * \\
(0.0237)\end{array}$ & $\begin{array}{l}0.0650 * * * \\
(0.0233)\end{array}$ \\
\hline Old & $\begin{array}{l}-166.3^{* * *} \\
(42.04)\end{array}$ & $\begin{array}{l}-91.44 * * \\
(37.66)\end{array}$ & $\begin{array}{l}-105.0 * * * \\
(38.65)\end{array}$ & $\begin{array}{l}-100.7^{* * *} \\
(38.09)\end{array}$ \\
\hline Young & $\begin{array}{l}-57.79 * * * \\
(15.53)\end{array}$ & $\begin{array}{l}-26.11 * \\
(14.35)\end{array}$ & $\begin{array}{l}-28.60 * \\
(15.65)\end{array}$ & $\begin{array}{l}-27.98^{*} \\
(14.84)\end{array}$ \\
\hline Left & $\begin{array}{r}21.41 \\
(20.94)\end{array}$ & $\begin{array}{r}21.69 \\
(19.15)\end{array}$ & $\begin{array}{l}35.68 * \\
(20.76)\end{array}$ & $\begin{array}{r}27.19 \\
(19.71)\end{array}$ \\
\hline Election & $\begin{array}{r}1.589 \\
(19.15)\end{array}$ & $\begin{array}{r}-2.848 \\
(15.26)\end{array}$ & $\begin{array}{r}-1.647 \\
(16.62)\end{array}$ & $\begin{array}{r}-2.413 \\
(15.74)\end{array}$ \\
\hline Unemployment & $\begin{array}{c}17.22 * \\
(9.896)\end{array}$ & $\begin{array}{r}11.16 \\
(9.169)\end{array}$ & $\begin{array}{c}17.26 * \\
(9.817)\end{array}$ & $\begin{array}{r}13.88 \\
(9.432)\end{array}$ \\
\hline New immigrants & $\begin{array}{r}85.00 \\
(60.11)\end{array}$ & $\begin{array}{l}187.7^{* * * *} \\
(64.40)\end{array}$ & $\begin{array}{l}184.4^{* * *} \\
(67.09)\end{array}$ & $\begin{array}{l}178.1 * * * \\
(64.76)\end{array}$ \\
\hline Other grants & $\begin{array}{l}-0.523 * \\
(0.270)\end{array}$ & $\begin{array}{r}-0.244 \\
(0.200)\end{array}$ & $\begin{array}{l}-0.356 * \\
(0.210)\end{array}$ & $\begin{array}{r}-0.271 \\
(0.203)\end{array}$ \\
\hline Constant & $\begin{array}{r}-1,058.4 \\
(1,017.8)\end{array}$ & $\begin{array}{l}-5,245.5^{* * *} \\
(1,161.8)\end{array}$ & $\begin{array}{r}-945.4 \\
(752.5)\end{array}$ & $\begin{array}{l}3,916.4^{* * *} \\
(1,210.7)\end{array}$ \\
\hline \multicolumn{5}{|l|}{ Instrument } \\
\hline Formula & $\begin{array}{l}3,658.8 * * * \\
(678.1)\end{array}$ & $\begin{array}{l}4,387.1 * * * \\
(648.7)\end{array}$ & $\begin{array}{l}3,734.7 * * * \\
(647.9)\end{array}$ & $\begin{array}{l}4,151.6 * * * \\
(655.1)\end{array}$ \\
\hline Provincial effects & yes & yes & yes & yes \\
\hline Time effects & yes & yes & yes & yes \\
\hline Fiscal capacity & cubic & quartic & $\begin{array}{l}\text { quadratic- } \\
\text { spline }\end{array}$ & $\begin{array}{l}\text { cubic- } \\
\text { spline }\end{array}$ \\
\hline Under-identification test & $24.86 * * *$ & $28.27 * * *$ & $25.40 * * *$ & $27.13 * * *$ \\
\hline Weak-identification test & 29.12 & 45.74 & 33.23 & 40.16 \\
\hline Number of observations & 280 & 280 & 280 & 280 \\
\hline AIC & $3,584.2$ & $3,518.8$ & $3,550.3$ & $3,533.0$ \\
\hline
\end{tabular}

Notes: Dependent variable is real per capita equalization grant.

We now discuss the effects of equalization grants on total provincial expenditure and its various components. As discussed before, we focus on both total provincial expenditure and on the 12 provincial expenditure categories. We present these results in Table 6 below. As indicated, the dependent variables are total provincial expenditure and its various categories all 
measured in real per capita terms. All regressions include provincial and year-specific fixedeffects and other exogenous co-variates. The control exogenous variables included are: personal income per capita, unemployment rate, real per capita non-equalization grants, a dummy variable for left-leaning government, a dummy variable for the presence of an election in the current year, and shares of the population that are new immigrants, below 20 years of age, and 65 years old and above. We report and focus our discussion on the coefficient estimates of the key variable of interest. The other variables are included in the estimation but suppressed for the sake of brevity. ${ }^{76}$ In addition to the control variables, we include various non-linear specifications for fiscal capacity as indicated. We also report standard errors which are robust to heteroskedasticity.

\section{TABLE 6: EFFECTS OF EQUALIZATION GRANTS ON THE LEVEL AND COMPOSITION OF GOVERNMENT EXPENDITURES,} 1981-2008

\begin{tabular}{|c|c|c|c|c|c|}
\hline Dependent Variable & $\begin{array}{l}11) \\
\text { OLS }\end{array}$ & $\begin{array}{c}(2) \\
2 S L S \\
\end{array}$ & $\begin{array}{c}13) \\
2 S L S\end{array}$ & $\begin{array}{c}(4) \\
2 S L S \\
\end{array}$ & $\begin{array}{c}(5) \\
2 S L S\end{array}$ \\
\hline Total government expenditure & $\begin{array}{l}0.827 \text { *** } \\
(0.177)\end{array}$ & $\begin{array}{l}0.823 * * \\
(0.370)\end{array}$ & $\begin{array}{l}0.637^{* *} \\
(0.317)\end{array}$ & $\begin{array}{c}0.672 * \\
(0.348)\end{array}$ & $\begin{array}{c}0.687^{* *} \\
(0.328)\end{array}$ \\
\hline Health & $\begin{array}{c}0.122 \text { ** } \\
(0.0580)\end{array}$ & $\begin{array}{c}0.292 * * * \\
(0.0956)\end{array}$ & $\begin{array}{c}0.207^{* * *} \\
(0.0730)\end{array}$ & $\begin{array}{c}0.262 * * * \\
(0.0862)\end{array}$ & $\begin{array}{c}0.238 * * * \\
(0.0785)\end{array}$ \\
\hline Education & $\begin{array}{r}0.0603 \\
(0.0663)\end{array}$ & $\begin{array}{r}-0.00658 \\
(0.255)\end{array}$ & $\begin{array}{r}-0.0704 \\
(0.246)\end{array}$ & $\begin{array}{r}-0.0289 \\
(0.251)\end{array}$ & $\begin{array}{r}-0.0488 \\
(0.247)\end{array}$ \\
\hline Social & $\begin{array}{l}0.00933 \\
(0.0531)\end{array}$ & 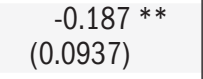 & $\begin{array}{l}-0.145 * \\
(0.0845)\end{array}$ & ${ }^{-0.217^{* *}}$ & $\begin{array}{c}-0.161 \text { * } \\
(0.0871)\end{array}$ \\
\hline Transport and Communication & $\begin{array}{r}0.0410 \\
(0.0302)\end{array}$ & $\begin{array}{r}0.0298 \\
(0.0500)\end{array}$ & $\begin{array}{r}0.0243 \\
(0.0460)\end{array}$ & $\begin{array}{r}0.0214 \\
(0.0492)\end{array}$ & $\begin{array}{r}0.0251 \\
(0.0469)\end{array}$ \\
\hline Resources & $\begin{array}{l}0.278^{* * *} \\
(0.0781)\end{array}$ & $\begin{array}{l}0.394 * * * \\
(0.147)\end{array}$ & $\begin{array}{l}0.354 * * * \\
(0.126)\end{array}$ & $\begin{array}{l}0.359 * * \\
(0.142)\end{array}$ & $\begin{array}{l}0.364 \text { *** } \\
(0.131)\end{array}$ \\
\hline Protection & $\begin{array}{l}-0.0310 * * * \\
(0.0109)\end{array}$ & $\begin{array}{r}-0.000196 \\
(0.0202)\end{array}$ & $\begin{array}{l}-0.0255^{*} \\
(0.0141)\end{array}$ & $\begin{array}{r}-0.0131 \\
(0.0167)\end{array}$ & $\begin{array}{r}-0.0189 \\
(0.0151)\end{array}$ \\
\hline Government Services & $\begin{array}{r}-0.00525 \\
(0.0199)\end{array}$ & $\begin{array}{r}-0.0309 \\
(0.0323)\end{array}$ & $\begin{array}{c}-0.0192 \\
(0.0281)\end{array}$ & $\begin{array}{r}-0.0301 \\
(0.0316)\end{array}$ & $\begin{array}{r}-0.0234 \\
(0.0291)\end{array}$ \\
\hline Environment & $\begin{array}{l}0.0495^{* * *} \\
(0.0146)\end{array}$ & $\begin{array}{l}0.0684 * * * \\
(0.0246)\end{array}$ & $\begin{array}{l}0.0509 * * \\
(0.0207)\end{array}$ & $\begin{array}{l}0.0657^{* * *} \\
(0.0236)\end{array}$ & $\begin{array}{l}0.0569 \text { *** } \\
(0.0216)\end{array}$ \\
\hline Recreation & $\begin{array}{l}0.0320 * * * \\
(0.0111)\end{array}$ & $\begin{array}{r}0.0149 \\
(0.0202)\end{array}$ & $\begin{array}{r}0.0241 \\
(0.0174)\end{array}$ & $\begin{array}{r}0.0173 \\
(0.0196)\end{array}$ & $\begin{array}{r}0.0212 \\
(0.0182)\end{array}$ \\
\hline Housing & $\begin{array}{l}0.0209 * * \\
(0.00936)\end{array}$ & $\begin{array}{l}0.0739 * * * \\
(0.0256)\end{array}$ & $\begin{array}{l}0.0583 * * * \\
(0.0219)\end{array}$ & $\begin{array}{l}0.0627 \text { ** } \\
(0.0243)\end{array}$ & $\begin{array}{l}0.0599 * * * \\
(0.0227)\end{array}$ \\
\hline Regional & $\begin{array}{r}-0.00334 \\
(0.00668)\end{array}$ & $\begin{array}{r}-0.000756 \\
(0.00892)\end{array}$ & $\begin{array}{r}0.00143 \\
(0.00814)\end{array}$ & $\begin{array}{r}-0.000261 \\
(0.00873)\end{array}$ & $\begin{array}{l}0.000913 \\
(0.00831)\end{array}$ \\
\hline Labour and Immigration & $\begin{array}{r}-0.00430 \\
(0.00408)\end{array}$ & $\begin{array}{c}-0.0149 * \\
(0.00881)\end{array}$ & $\begin{array}{r}-0.0116 \\
(0.00774)\end{array}$ & $\begin{array}{l}-0.0150 * \\
(0.00849)\end{array}$ & $\begin{array}{r}-0.0128 \\
(0.00796)\end{array}$ \\
\hline Fiscal Capacity & & cubic & quartic & $\begin{array}{r}\text { quadratic- } \\
\text { spline }\end{array}$ & $\begin{array}{l}\text { cubic- } \\
\text { spline }\end{array}$ \\
\hline
\end{tabular}

Notes: The dependent variables are real per capita government expenditures as indicated. The number of observations is 280. Each coefficient estimate is obtained from a separate regression. Robust standard errors in parentheses. Significance levels are indicated by *** for one per cent, ** for five per cent, and * for 10 per cent. All regressions include provincial-and year-specific fixed-effects and other exogenous co-variates. The control exogenous variables included are: personal income per capita, unemployment rate, real per capita nonequalization grants, a dummy variable for left-leaning government, a dummy variable for the presence of an election in the current year, shares of the population comprised of new immigrants, below 20 years of age, and 65 years old and above. In columns (2) to (5), equalization grant is instrumented with the equalization-grant allocation formula after controlling for fiscal capacity as indicated.

\footnotetext{
${ }^{76}$ The detailed regression results for the total expenditure and its various categories are available upon request.
} 
In column (1), we represent results obtained using the OLS estimation method. Note that each coefficient estimate in Table 5 is obtained from a separate regression with the various dependent variables as shown. The OLS results show that equalization grants have a statistically significant positive effect on total provincial government spending. The results indicate that a $\$ 1.00$ increase in per capita equalization grants is associated with a $\$ 0.83$ increase in per capita total provincial government spending. This result is broadly consistent with the findings of previous related studies.

The OLS results of column (1) also show that equalization grants have statistically significant positive effects on real per capita provincial spending on health-care services (Health), resource conservation and industrial assistance (Resource), environment, recreation and culture, and housing. The results also show that equalization grants have a statistically significant effect on government spending on protection of persons and property. However, we do not find a significant effect on the other expenditure categories. The insignificant effects of equalization grants on tax-base-enhancing expenditures, such as education and transport and communication, is not surprising and somewhat consistent with the predictions of theoretical studies such as Dahlby. ${ }^{77}$

So far, we have focused on OLS estimation results assuming that equalization grants are exogenous. However, as we have argued before, the OLS estimation results may be biased as the equalization grant is endogenous. Consequently, we present the IV estimation results in columns (2) through (5) of Table 6. We use the equalization-grant formula as our main identification strategy after controlling for a non-linear function of relative fiscal capacity as indicated. The specifications of columns (2) to (5) are basically similar and they differ only in the non-linear functional form of fiscal capacity. Based on adjusted R-squared, the regressions with quartic specification for fiscal capacity show the best fit for the data. ${ }^{78}$ So, we focus our discussion on results presented in column (3), which control for a quartic form of fiscal capacity.

Column (3) presents the IV estimation results that control for a quartic function of fiscal capacity. The results indicate that equalization grant has a positive and statistically significant effect on per capita provincial expenditure. The numerical magnitude of the result is lower than what we found under OLS, suggesting the potential bias of OLS results. The results suggest that a $\$ 1.00$ increase in per capita equalization grants is associated with about a $\$ 0.64$ increase in real per capita provincial expenditure. This also implicitly suggests that the remaining effect of the equalization grants is to help reduce the tax rates that otherwise would have been higher than in the presence of the equalization program. Thus, the results are consistent with the proposition that equalization grants have stimulative effects on provincial spending. As before, we report and focus our discussion on the coefficient estimates of the key variables of interest. The other variables are included in the estimation but not reported for the sake of brevity. In addition to the control variables, we include various non-linear specifications for fiscal capacity.

\footnotetext{
77 Dahlby, "The Incentive Effects."

78 The corresponding adjusted R-square statistics for each coefficient estimate are not reported for the sake of brevity.
} 
Comparing results of columns (1) and (3), we see that the numerical magnitudes of the effects of equalization grants on the various components of provincial spending are slightly higher when we use the IV estimations. Empirical results reported in column (3) show that equalization grants have statistically significant positive effects on real per capita provincial spending on health-care services (Health), resource conservation and industrial assistance (Resource), environment, and housing. The results indicate that a $\$ 1.00$ increase in per capita equalization grants is associated with a $\$ 0.21$ increase in per capita provincial expenditure on health-care services, a $\$ 0.35$ increase in per capita provincial expenditure on resource conservation and industrial assistance, a $\$ 0.05$ increase in per capita spending on the environment, and a $\$ 0.058$ increase in spending on housing.

The results also show that equalization grants have a weak negative effect on government spending on social services and protection of persons and property. These coefficients are significant only at the 10 per cent level. However, we do not find a significant effect of equalization grants on the other expenditure categories. The insignificant effects of equalization grants on tax-base-enhancing expenditures, such as education and transport and communication, is consistent with the predictions of theoretical studies such as Dahlby. ${ }^{79}$

\section{CONCLUSIONS}

The fiscal equalization program has long helped to underpin the Canadian federation. As the program was designed to address fiscal disparities among provinces, the grant allocation formula compensates recipient provinces when their per capita tax base is below the standard per capita tax base. Thus, the key elements of the equalization formula can be influenced by the fiscal decisions of the provincial government. This provides recipient governments the incentive to change their fiscal policies in order to raise their equalization entitlements. In this paper, we investigate how the Canadian equalization system influences the recipient provinces' fiscal policy incentives. We provide empirical evidence on the effects of equalization grants on tax policy and the level and composition of provincial expenditure using Canadian provincial data over the period 1981-2008.

We first conduct an empirical investigation of the incentive effects of equalization grants on business and personal income taxes, which are arguably the two largest sources of provincial tax revenue in Canada. Our empirical results suggest that equalization grants provide provincial governments an incentive to raise their business and personal income tax rates. We also find that this incentive effect works through the equalization-base effect for business income tax. For personal income tax, on the other hand, the results indicate that equalization grants influence the tax policy incentives through both the equalization-base and -rate effects, although the latter seems to be driven by Quebec. The incentive effects of equalization grants clearly cause distortion in provincial tax policy, as the recipient governments underestimate the true deadweight cost associated with the higher tax rates. Indeed, the empirical results suggest that if equalization grants were substituted with block grants that are not related to taxing capacity, business and personal income tax rates would be lower in the grant-receiving provinces.

79 Dahlby, "The Incentive Effects." 
Our empirical results also suggest that equalization grants stimulate provincial spending and affect the various provincial expenditure categories. Results from our preferred regression indicates that a $\$ 1.00$ increase in per capita equalization-grant raises per capita total provincial expenditure by about $\$ 0.64$. This is broadly consistent with the flypaper literature and the estimated results are well within the ranges of results obtained in other similar studies.

Empirical estimates of the effects of equalization grants on the composition of provincial spending also reveal that not all provincial spending categories are affected by equalization grants. We find that equalization grants have a significant positive effect on provincial spending on health-care services, resource conservation and industrial assistance, environment, and housing. However, we do not find a significant effect on the other expenditure categories.

\section{About the Author}

Ergete Ferede is currently an associate professor of Economics at Grant MacEwan University and Fellow of the Institute of Public Economics, University of Alberta. His B.A. and M.Sc. are from Addis Ababa University in Ethiopia and his Ph.D. is from the University of Alberta in 2005. His main research areas are public finance and economic growth. His research has been published in National Tax Journal, International Tax and Public Finance, Small Business Economics, etc. He has previously taught a wide range of courses at Addis Ababa University, University of Alberta, and University of Windsor. He was a winner of the University of Windsor Teaching Score Award for the academic year 2005/6. 


\title{
ABOUT THE SCHOOL OF PUBLIC POLICY
}

The School of Public Policy will become the flagship school of its kind in Canada by providing a practical, global and focused perspective on public policy analysis and practice in areas of energy and environmental policy, international policy and economic and social policy that is unique in Canada.

The mission of The School of Public Policy is to strengthen Canada's public service, institutions and economic performance for the betterment of our families, communities and country. We do this by:

- Building capacity in Government through the formal training of public servants in degree and non-degree programs, giving the people charged with making public policy work for Canada the hands-on expertise to represent our vital interests both here and abroad;

- Improving Public Policy Discourse outside Government through executive and strategic assessment programs, building a stronger understanding of what makes public policy work for those outside of the public sector and helps everyday Canadians make informed decisions on the politics that will shape their futures;

- Providing a Global Perspective on Public Policy Research through international collaborations, education, and community outreach programs, bringing global best practices to bear on Canadian public policy, resulting in decisions that benefit all people for the long term, not a few people for the short term.

Our research is conducted to the highest standards of scholarship and objectivity. The decision to pursue research is made by a Research Committee chaired by the Research Director and made up of Area and Program Directors. All research is subject to blind peer-review and the final decision whether or not to publish is made by an independent Director.

\author{
The School of Public Policy \\ University of Calgary, Downtown Campus \\ 906 8th Avenue S.W., 5th Floor \\ Calgary, Alberta T2P $1 \mathrm{H} 9$ \\ Phone: 4032107100
}

\section{DISTRIBUTION}

Our publications are available online at www.policyschool.ca.

\section{DISCLAIMER}

The opinions expressed in these publications are the authors' alone and therefore do not necessarily reflect the opinions of the supporters, staff, or boards of The School of Public Policy.

\section{COPYRIGHT}

Copyright (C) 2014 by The School of Public Policy.

All rights reserved. No part of this publication may be reproduced in any manner whatsoever without written permission except in the case of brief passages quoted in critical articles and reviews.

\section{ISSN}

1919-112x SPP Research Papers (Print)

1919-1138 SPP Research Papers (Online)

\section{DATE OF ISSUE}

September 2014

\section{MEDIA INQUIRIES AND INFORMATION}

For media inquiries, please contact Morten Paulsen at 403-453-0062.

Our web site, www.policyschool.ca, contains more information about The School's events, publications, and staff.

\section{DEVELOPMENT}

For information about contributing to The School of Public Policy, please contact Courtney Murphy by telephone at 403-210-7201 or by e-mail at cdmurphy@ucalgary.ca. 


\section{RECENT PUBLICATIONS BY THE SCHOOL OF PUBLIC POLICY}

WIRELESS COMPETITION IN CANADA: DAMN THE TORPEDOES! THE TRIUMPH OF POLITICS OVER ECONOMICS http://policyschool.ucalgary.ca/sites/default/files/research/church-wirelessupd2014-v6.pdf Jeffrey Church and Andrew Wilkins | August 2014

THE FUTURE OF ENERGY REGULATION AND POLICY DEVELOPMENT: A SUMMARY PAPER http://policyschool.ucalgary.ca/sites/default/files/research/energyregul5.pdf Shantel Beach, Andrew Wilkins and Jennifer Winter | August 2014

"IT'S ALL ABOUT THE MONEY": CRIME IN THE CARIBBEAN AND ITS IMPACT ON CANADA http://policyschool.ucalgary.ca/sites/default/files/research/ross-caribbeancrime.pdf Cameron Ross | July 2014

RISKY BUSINESS: THE ISSUE OF TIMING, ENTRY AND PERFORMANCE IN THE ASIA-PACIFIC LNG MARKET

http://policyschool.ucalgary.ca/sites/default/files/research/moore-Ing-onl.pdf

David Hackett, Roman Karski, Michal Moore, Leigh Noda, Mark Pilcher and Jennifer Winter | July 2014

WHO, OR WHAT, IS TO BLAME FOR THE ACCUMULATION OF DEBT IN ONTARIO AND QUEBEC (AND WHAT WILL IT TAKE TO STOP THE BLEEDING?) http://policyschool.ucalgary.ca/sites/default/files/research/kneebone-ontdebt3.pdf Margarita Wilkins and Ron Kneebone | July 2014

THE IMPACT OF FOREIGN INVESTMENT RESTRICTIONS ON THE STOCK RETURNS OF OIL SANDS COMPANIES http://policyschool.ucalgary.ca/sites/default/files/research/beaulieau-foreign-inv.pdf Eugene Beaulieu and Matthew Saunders | June 2014

FROM TRIAL TO TRIUMPH: HOW CANADA'S PAST FINANCIAL CRISES HELPED SHAPE A SUPERIOR REGULATORY SYSTEM http://policyschool.ucalgary.ca/sites/default/files/research/savage-financeevol.pdf Lawrie Savage | May 2014

THE FREE RIDE IS OVER: WHY CITIES, AND CITIZENS, MUST START PAYING FOR MUCH-NEEDED INFRASTRUCTURE http://policyschool.ucalgary.ca/sites/default/files/bazelmintz-urban-growth.pdf Philip Bazel and Jack Mintz | May 2014

ALBERTA CITIES AT THE CROSSROADS: URBAN DEVELOPMENT CHALLENGES AND OPPORTUNITIES IN HISTORICAL AND COMPARATIVE PERSPECTIVE http://policyschool.ucalgary.ca/sites/default/files/research/taylor-ab-cities-5.pdf Anna Kramer, Marcy Burchfield and Zack Taylor | May 2014

ONTARIO'S EXPERIMENT WITH PRIMARY CARE REFORM

http://policyschool.ucalgary.ca/sites/default/files/ontario-health-care-reform.pdf Gioia Buckley and Arthur Sweetman | May 2014

THE MIDDLE POWER AND THE MIDDLE KINGDOM: SECURING CANADA'S PLACE IN THE NEW CHINA-U.S. ECONOMIC AND STRATEGIC WORLD ORDER http://policyschool.ucalgary.ca/sites/default/files/dobson-china-communique.pdf Wendy Dobson | April 2014

SAFETY IN NUMBERS: EVALUATING CANADIAN RAIL SAFETY DATA

http://policyschool.ucalgary.ca/sites/default/files/research/winter-rail-safety-communique.pdf Jennifer Winter | April 2014

CHINA'S STATE-OWNED ENTERPRISES AND CANADA'S FDI POLICY

http://policyschool.ucalgary.ca/sites/default/files/research/dobson-china.pdf Wendy Dobson | March 2014 